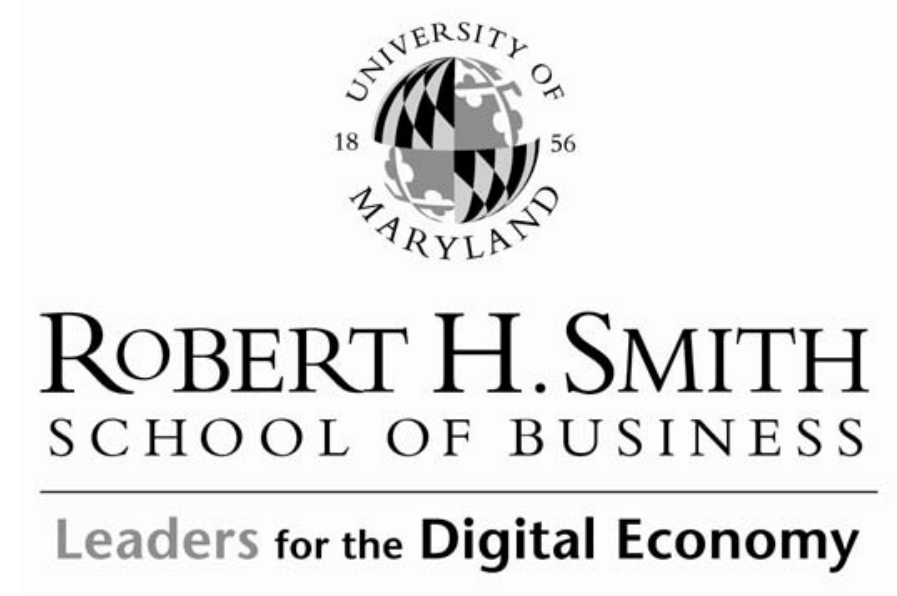

Working Paper No. RHS-06-032

March 2006

\title{
What determines protection of property rights? An Analysis of Direct and Indirect Effects
}

\author{
Meghana Ayyagari \\ Asli Demirgüç-Kunt \\ Vojislav Maksimovic
}

This Papercan be downloaded without charge from the Social Science Research Network Electronic Paper Collection http://ssm.com/a bstra ct $=891750$ 


\title{
What determines protection of property rights? An Analysis of Direct and Indirect Effects
}

\author{
Meghana Ayyagari
}

\author{
Asli Demirgüç-Kunt
}

\author{
Vojislav Maksimovic*
}

March 13, 2006

\begin{abstract}
Using cross-country data, this paper evaluates historical determinants of protection of property rights. We examine four historical theories that focus on conceptually distinct causal variables in shaping institutions, as captured by legal origin, endowments, ethnic diversity and religion. There is only one realization of the data with relatively few observations, which have by now been well explored in the literature. Given the correlations between the explanatory variables, it is difficult to fashion empirical tests which are consistent in their treatment of the competing theories and to know which regressions to take seriously, giving rise to competing interpretations in the literature. We use Directed Acyclic Graph (DAG) methodology to identify which historical factors are direct determinants of property rights protection and which are not, and subject the outcomes to a battery of robustness tests. The empirical results support ethnic fractionalization as a robust determinant of property rights protection. Despite the attention it has received in the literature, the impact of legal origin on protection of property rights appears fragile and dependent on the inclusion of transition economies in the sample .
\end{abstract}

Keywords: Property Rights, Legal Origin, Endowments, Directed Acyclic Graphs

JEL Classification: K4, D23.

*Ayyagari: School of Business, George Washington University; Demirgüç-Kunt: World Bank; Maksimovic: Robert H. Smith School of Business at the University of Maryland. We would like to thank Thorsten Beck, Stijn Claessens, Patrick Honohan, Aart Kraay, Ross Levine, Alan Winters and seminar participants at the University of Maryland for helpful comments. This paper's findings, interpretations, and conclusions are entirely those of the authors and do not necessarily represent the views of the World Bank, its Executive Directors, or the countries they represent. 


\section{Introduction}

Protection of property rights is a key determinant of the efficient operation of contracts and the development of financial institutions. The critical question is why some countries have managed to develop strong protection of property rights, while others have not. A substantial body of theoretical work tries to explain the historical determinants of these differences. There is also a growing body of empirical work that assesses the relative contribution of different historical determinants in cross-country variation of property rights protection.

However, attempts at empirical validation of institutional theories face challenges stemming from severe data limitations. There is only one realization of the data with relatively few observations, which have by now been well explored in the literature. Given the overlapping nature of the theories of property rights, it is difficult to fashion empirical tests which are consistent in their treatment of the competing theories. Different investigators focusing on different variables may find different specifications persuasive to test and to report. Moreover, it is possible to quickly develop a heuristic about which variables will be jointly significant in the regressions and to obtain results that appear to confirm the heuristic in the sample data. This is a matter of concern because out-ofsample tests are not feasible. Similar concerns exist in the asset pricing literature, where Foster, Smith and Whaley (1997) show that there is a significant bias "when a researcher has had access to many potential regressors (or, equivalently, has read past research that suggested which regressors to choose)”. ${ }^{1}$

\footnotetext{
${ }^{1}$ The implicit assumption in standard statistical tests (F-test, R-square) is that only one test is conducted with a particular data set. However using the same dataset repeatedly in future empirical studies is open to data instigated pretest biases as discussed in Leamer (1978). While the institutions literature has so far ignored these limitations, data snooping biases have been studied extensively in the asset pricing literature
} 
In this paper we address these issues by adopting an empirical approach that relies on the data rather than investigator discretion to specify a model linking property rights and a set of potential explanatory variables advanced in the literature. Our approach treats the potential explanatory variables together and evenhandedly, and allows us to explore relations between them. Empirically, we use cross country data on 158 countries and evaluate four theories concerning historical determinants of property rights protection. While there are overlaps, the four theories focus on different and distinct causal mechanisms in shaping institutions, as captured by legal origin, endowments, ethnic diversity and religion. We begin with a set of variables suggested by the institutional theories and then allow the data to reject potential causal relations between these variables and property rights protection. At the end of the process, we are left with a set of potential causal relations between our measure of property rights protection and the set of proposed explanatory variables. The procedure also suggests possible relations among the set of proposed explanatory variables.

Specifically, we employ Directed Acyclic Graph (DAG) methodology developed in computer science that allows us to consistently evaluate the four theories concerning historical determinants of property rights protection (Spirtes, Glymour, and Scheines, 2000). This algorithm uses the correlation matrix of a set of variables to determine whether a variable meets certain criteria, derived from probability and graph theory, for it to be classified as a direct or indirect cause of another variable. Using this methodology, whose purpose is to discover causal patterns in the data, we are able to identify which historical factors are direct determinants of property rights protection and which are not.

(Merton, 1987; Black, 1993; Lo and MacKinlay, 1990, 1997). Lo and MacKinlay (1990) in particular show that standard tests of significance are not valid when the construction of the test statistics is influenced by empirical relations derived from the very same data to be used in the test. 
We subject the results to a battery of robustness tests and compare our methodology to regression analysis to illustrate how a regression-based analysis of the question can lead to misleading results.

Our results show that at the $5 \%$ and $10 \%$ significance level, Common Law, Latitude and Ethnic Fractionalization are all significant predictors of property rights protection where as Catholic Religion is not. However at the $1 \%$ significance level, only ethnic fractionalization is a causal determinant of property rights protection. Further Ethnic Fractionalization is the only variable which is robust to different sample compositions where as the effect of Latitude and Common Law is strongly dependent on the sample of countries under study. The data offers only limited support for the proposition that Common Law origin or Latitude is a determinant of property rights protection and the support is not robust to different definitions of the variable or sample composition

Our paper is related to Beck, Demirguc-Kunt and Levine (2003) and Ayyagari, Demirguc-Kunt and Maksimovic (2005a). Using firm-level survey data, Ayyagari, Demirguc-Kunt and Maksimovic (2005a) evaluate determinants of firm level perceptions of property rights protection and find the ethnic fractionalization and endowments view to explain a greater proportion of variation in the data compared to other historical factors However, they consider one variable at a time and do not rule out any variable. Beck, Demirguc-Kunt and Levine (2003) find more evidence supporting the law and finance view. However, in this paper we are able to illustrate how the regression-based methodologies, as normally applied, can be misleading in identifying causal factors and that legal origin is not a robust determinant of property rights protection. 
Our paper is most closely related in spirit to Kormendi and Meguire (1985), Barro (1991), Levine and Renelt (1992) and Sala-i-Martin (1997). These authors examine a parallel problem: determining which of many possible proposed macroeconomic variables could reliably be classified as predictors of economic growth. Kormendi and Meguire (1985), Barro (1991), and Levine and Renelt (1992) use Extreme Bounds Analysis (EBA) and Sala-i-Martin (1997) uses a similar technique. DAG analysis has several advantages over these methods. Whereas these methods start from an equation that is specified by the researcher that embodies a causal ordering that is then tested, DAG can endogenously discover the causal ordering. Moreover, whereas EBA treats one relation at a time, the graphs produced by DAG show robust relations between all the variables being analyzed, taking into account the implications of robust relations elsewhere in the system, on the causal ordering in a specific relation. The DAG analysis also allows the researcher to explore the implications of imposing a causal restriction in one relation on robust relations throughout the system.

The remainder of the paper is organized as follows. Section 2 discusses the hypotheses we investigate. Section 3 outlines the empirical methodology and the data. Section 4 applies the methodology to identify historical determinants of property rights and presents the main results, comparing them to regression analysis. Section 5 provides additional robustness results, with different samples of countries and alternative variable definitions and compares DAG methodology to Extreme Bounds Analysis and a methodology for examining robustness due to Sala-i-Martin (1997). Section 6 concludes. 


\section{Institutional Theories of Property Rights Protection}

We evaluate four potential historical determinants of property rights protection.

First, the law and finance view predicts that historically determined differences in legal traditions help explain differences in protection of property rights today (La Porta, Lopez-de-Silanes, Shleifer and Vishny, hereafter LLSV, 1998). Focusing on the differences between the two most influential legal traditions, the British Common law and the French Civil law, this theory holds that legal traditions differ in terms of the priority they attach to protecting the rights of private investors against the state (Hayek, 1960). The reasons for the differences can be found in the way different legal traditions evolved. While the British Common law evolved to protect private property owners against the crown (Merryman, 1985), the French Civil law evolved to eliminate the role of a corrupt judiciary by restraining courts from interfering with state policy and to solidify the power of the state. Over time, these trends led French Civil law to focus on the rights of the state and less on the rights of the individual investors when compared to British Common law (Mahoney, 2001). Thus, the law and finance theory predicts legal origin to be an important determinant of property rights protection, with countries that have adopted the British Common law tradition placing much more emphasis on such protections than countries with the French Civil law tradition. As these legal origins spread around the world through colonization, British colonizers brought with them a legal tradition that stressed private property rights protection, while French colonizers spread a legal tradition that is less conducive to such protection.

Second, the endowment view emphasizes the role of geography and the disease environment in shaping the institutional environment and the property rights that 
underline such development. Acemoglu, Johnson and Robinson (2001) argue that it is not the identity of the colonizer but the colonization strategy that determined the extent of property rights protection. In settler colonies such as the United States, Australia and New Zealand, Europeans settled themselves and created institutions to protect private property rights and check the power of the state. On the other hand, in colonies where the colonization strategy was to extract resources from the indigenous population rather than settle, Europeans did not create institutions to protect property rights. Instead, they created institutions to empower the elite to extract natural resources, as in the case of Congo, Ivory Coast, and Latin America. Acemoglu et al. (2001) also argue that the colonization strategy was very much determined by the feasibility of settlement and the disease environment. Consistent with this theory, countries that are closer to the equator tended to have a more tropical climate that was inhospitable to European settlers and therefore more likely fostered extractive institutions as opposed to institutions that protect property rights. Engerman and Sokoloff (1997) note another channel through which geographical endowments shape property rights protection. They show that agriculture in southern North America and most of South America is conducive to large plantations, and thus have led colonists to develop institutions to protect few landowners against many peasants. In contrast, North America's agriculture is conducive to small farms, so more egalitarian institutions emerged, with greater emphasis on protection of property rights.

Third, political theories predict that governments become more interventionist as ethnic heterogeneity of a country increases. Studies have shown that in more ethnically diverse countries, the groups that come to power implement policies that expropriate as 
much as possible from other ethnic groups, restrict their rights, and prohibit the growth of industries or sectors that threaten the ethnic group in power (Alesina et al., 2003; Easterly and Levine, 1997) ${ }^{2}$. Thus the Ethnic Diversity view would predict that countries with greater ethnic fractionalization are less likely to protect property rights.

Finally, many scholars also argue that religion shapes national views regarding protection of property rights (LLSV, 1999; Stulz and Williamson, 2003). Scholars argue that the Catholic religion fostered authoritarian societies, rather than egalitarian ones that lead to powerful bonds between church and the state, limiting private property rights protection (Putnam, 1993; Landes, 1998). Thus, the fourth view, Religion, predicts that religious differences and the system of beliefs and culture that stem from such differences can explain differences in property rights protection across countries.

Each theory argues very distinct mechanisms about how different historical factors - legal tradition, disease and geography endowments, ethnic diversity, and religion - shaped national views toward property rights protection. Though the theories are not mutually exclusive, they do focus on very different mechanisms. We empirically evaluate which of these historical mechanisms are causally related to property rights protection today.

\section{Directed Acyclic Graphs}

The Directed Acyclic Graph (DAG) methodology selects models that are compatible with the data using an objective algorithm derived from a small number of axioms. The models selected by DAG can then be submitted to a standard regression

\footnotetext{
${ }^{2}$ As noted by Alesina et al (2003), ethnic fractionalization has also been found empirically to predict lower levels of trust, less efficient public services and less favorable economic outcomes in US localities.
} 
analysis for parameter estimation. The output of the algorithm is a set of graphical relations between the different variables. The graphs provide a compact representation of joint probability distributions with the nodes of the graphs representing the random variables and the edges (or the lack thereof) connecting the nodes, representing conditional independence assumptions. We describe below the assumptions behind linking probability dependence/independence relations to causal inference and illustrate how the software program TETRAD produces a causal pattern from raw data and conclude with a specific example of how supplementing regression analysis with DAGs can be useful and provides more accurate results.

A directed acyclic graph (DAG) is a picture or a path diagram representing causal flow between or among a set of variables. For example, given a set of three vertices: $\{X 1$, $\mathrm{X} 2, \mathrm{X} 3\}$, and a set of two edges among these vertices: $\{\mathrm{X} 1 \rightarrow \mathrm{X} 2, \mathrm{X} 2 \rightarrow \mathrm{X} 3\}$, the corresponding DAG would be:

\section{$\mathrm{X} 1 \rightarrow \mathrm{X} 2 \rightarrow \mathrm{X} 3$.}

For the above DAG to be ascribed causal inference, we need the Causal Markov Condition. Formally, the Causal Markov Condition states that for a variable Y and any set of variables $\mathrm{X}$ that does not include the effects of $\mathrm{Y}, \mathrm{Y}$ is probabilistically independent of $\mathrm{X}$ conditional on the direct causes of $\mathrm{Y} .^{3}$ The intuition in the Causal Markov assumption is that each variable is independent of all other variables that are not its effects, conditional on its immediate causes. So the above DAG implies that X3 is independent of X1 conditional on X2. . The Causal Markov Condition also asserts that if $X$ and $Y$ are related only as effects of a common cause $Z$, then $X$ and $Y$ are probabilistically independent conditional on $Z$.

\footnotetext{
3 The Causal Markov Condition is equivalent to d-separation in graph theory, Pearl (1988).
} 
The key intuition in discovering a causal pattern from observational data is that, under the Causal Markov condition, observed patterns of statistical independence limit the number of possible causal graphs compatible with the observed data. Specifically, when considering the individual relation between an outcome variable $\mathrm{Y}$ and potential cause $\mathrm{X}_{\mathrm{i}}$ in DAG analysis, the Causal Markov Condition requires that a variable $\mathrm{X}_{\mathrm{i}}$ is identified as being a direct cause of outcome variable $\mathrm{Y}$ only if $\mathrm{X}_{\mathrm{i}}$ and $Y$ are dependent conditional on every subset of $\boldsymbol{X}-\left\{\mathrm{X}_{\mathrm{i}}, Y\right\}$ (Scheines, 2001). In contrast, in regression analysis, $\mathrm{X}_{\mathrm{i}}$ is identified as being a significant predictor of outcome variable $\mathrm{Y}$ only if $\mathrm{X}_{\mathrm{i}}$ and $Y$ are dependent conditional on the entire regressor matrix i.e. exactly the set $\boldsymbol{X}-\{X i$ , $Y$ \}. We illustrate this in the following sub-sections.

Consider again the above example with variables X1, X2 and X3, where, say, we observe from the data that $\mathrm{X} 1$ and $\mathrm{X} 3$ are independent conditioning on $\mathrm{X} 2$. This observation implies that the causal graph

\section{$\mathrm{X} 1 \rightarrow \mathrm{X} 2 \leftarrow \mathrm{X} 3$}

is incompatible with the data, since if $\mathrm{X} 1$ and $\mathrm{X} 3$ were both causes of $\mathrm{X} 2$, then conditioning on X2 would render X1 and X3 statistically dependent ${ }^{4}$. The causal graphs that are compatible with the observed independence pattern include the one we saw before

\section{$\mathrm{X} 1 \rightarrow \mathrm{X} 2 \rightarrow \mathrm{X} 3$}

as well as

\footnotetext{
${ }^{4}$ The same is more intuitive to understand when we view this as the relationship between two independent causes (X1 and X3) after we condition on a common effect (X2). Consider the following example from Pearl (1988), in which there are two independent causes for a car refusing to start: having no gas and having a dead battery. So dead battery $\rightarrow$ car won’t start $\leftarrow$ no gas. Having information that the battery is charged does not tell us anything about whether or not there is gas in the fuel tank. But having information that the battery is charged after knowing that the car won't start indicates that the gas tank must be empty. So independent causes are made dependent by conditioning on a common effect.
} 


\section{$\mathrm{X} 1 \leftarrow \mathrm{X} 2 \leftarrow \mathrm{X} 3$ and $\mathrm{X} 1 \leftarrow \mathrm{X} 2 \rightarrow \mathrm{X} 3$}

We can take the observed data, either in raw form or as correlations (and the independence conditions they embody) as input, and use algorithms to search for all compatible graphs.

In some cases there is not enough information in the data to fully specify a unique graph and to identify the dependent from the independent variables. The number of compatible graphs can often be significantly reduced, (maybe to even one) with added assumptions based on prior theory or knowledge of temporal order of the variables. Thus, for example, prior knowledge that X2 precedes X3 rules out two of the preceding graphs.

While the use of prior knowledge to specify models is an integral component of all empirical work, DAG methodology immediately reveals how an a priori assumption interacts with the data to rule out relations about which the researcher may have no prior information. Thus, for example, a restriction based on theory that X2 precedes X3 also implies in the above example that $\mathrm{X} 1 \rightarrow \mathrm{X} 2$.

In addition to the Causal Markov condition, the DAG methodology relies on two other principal axiomatic assumptions:

(a) Faithfulness (or Stability): Assuming that a population is Faithful is to assume that whatever independencies occur in it arise not from incredible coincidence but rather from structure.

If there are any independence relations in the population that are not a consequence of the Causal Markov condition, then the population is unfaithful. For instance, if in the above example we had $\{\mathrm{X} 1 \rightarrow \mathrm{X} 2, \mathrm{X} 2 \rightarrow \mathrm{X} 3$ and $\mathrm{X} 1 \rightarrow \mathrm{X} 3\}$, applying 
the Causal Markov Condition gives no independence relations. However, by coincidence $\mathrm{X} 1$ could be independent of X3 (Say X1 has a negative direct effect on X3 but X1 has a positive effect on $\mathrm{X} 2$ which has a positive effect on X3. If the direct and indirect effects of X1 on X3 exactly cancel each other, then there will be no association between X1 and $\mathrm{X} 3)$. In such a case, the population is said to be unfaithful to the causal graph that generated it.

(b) Causal Sufficiency: Causal Sufficiency is satisfied if we have measured all the common causes of the measured variables.

The causal sufficiency assumption is similar to the standard assumption in most econometric specifications where we assume that there are no latent (absent) variables that are driving the covariance matrix and that the variables in the dataset are sufficient to explain relations among the variables.

The DAG methodology is related to another methodology which has been used in the literature to check for robustness of estimated relations, Extreme Bounds Analysis. Extreme Bounds Analysis starts with a statistically significant regression between an apriori determined outcome variable $\mathrm{Y}$ and variable $\mathrm{X}_{\mathrm{i}}$ which is believed to be a direct cause of $\mathrm{Y}$ and that belongs to a set of potentially relevant causal variables $\mathbf{X}$. If $\mathrm{X}_{\mathrm{i}}$ causes $Y$, then regressing $\mathrm{Y}$ on both $\mathrm{X}_{\mathrm{i}}$ and any subset of $\boldsymbol{X}-\left\{\mathrm{X}_{\mathrm{i}}, Y\right\}$ should not affect the sign and statistical significance of the relation between $\mathrm{X}_{\mathrm{i}}$ and $Y$ (Leamer,1983). Accordingly, in EBA, $\mathrm{Y}$ is in turn regressed on both $\mathrm{X}_{\mathrm{i}}$ and every subset of $\boldsymbol{X}-\left\{\mathrm{X}_{\mathrm{i}}, Y\right\}^{5}$ to find the widest range of coefficient estimates on $\mathrm{X}_{\mathrm{i}}$, that standard hypothesis tests do not reject. The highest and lowest values of the coefficients of $X_{i}$ are determined and the

\footnotetext{
${ }^{5}$ Due to concerns about multicollinearity and also the number of iterations involved when we have many variables, most studies using EBA restrict the conditioning subset to three variables, including Kormendi and Meguire (1985), Barro (1991), Levine and Renelt (1992) and Sala-i-Martin (1997).
} 
extreme upper bound is defined by the group of $\mathbf{X}$ variables that produces the maximum value of $b_{i}$ plus two standard deviations and the extreme lower bound is defined as minimum value of $b_{i}$ plus two standard deviations. If the original relation between $\mathrm{Y}$ and variable $X_{i}$ remains statistically significant and of the same sign at the two extreme bounds, then, the relation between the two variables is considered robust. Note that EBA can only be performed on regressor variables that are significant to start with in the original regression.

Analogously, when considering the individual relation between an outcome variable $\mathrm{Y}$ and potential cause $\mathrm{X}_{\mathrm{i}}$ in DAG analysis, the Causal Markov Condition requires that a variable $\mathrm{X}_{\mathrm{i}}$ is identified as being a direct cause of outcome variable $\mathrm{Y}$ only if $\mathrm{X}_{\mathrm{i}}$ and $Y$ are dependent conditional on every subset of $\boldsymbol{X}-\left\{\mathrm{X}_{\mathrm{i}}, Y\right\}$ (Scheines, 2001). However, DAG analysis has several advantages over EBA. DAG can endogenously discover the causal ordering from the data, which in EBA is required to be specified by the researcher. In addition, DAG considers the whole system of variables $\mathbf{X}$, with the graphs taking into account the implications of robust relations elsewhere in the system, on the causal ordering in a specific relation. EBA on the other hand treats only one relation at a time. The DAG analysis also allows the researcher to explore the implications of imposing a causal restriction in one relation on robust relations throughout the system.

\section{Data}

We examine a sample of 158 countries for which data on property rights protection is available. Table 1 shows the countries in our sample. Property Rights is an 
index of the degree to which the government protects private property and enforces laws that protect private property. The data are for 2000 and were obtained from the Index of Economic Freedom constructed by the Heritage Foundation. The index is available for a large number of countries and has been recently used in several papers including Johnson, Kaufmann, and Zoido-Lobaton (1998), LLSV (1999, 2002), Beck, DemirgucKunt and Levine (2003) and Claessens and Laeven (2003). Within our sample, property rights varies from a score of 5 for countries with good property rights protection like the United States to 1 for countries like the Congo Democratic Republic, Libya and Vietnam.

The countries in our sample belong to different legal traditions and the data on legal families is taken from LLSV (1998). Since the literature has argued that common law countries have a significant advantage over civil and socialist law traditions and regressions typically only distinguish between common law countries and civil law countries (see, for instance, LLSV(1998), Stulz and Williamson (2003), Beck, DemirgucKunt and Levine (2003)), we use the dummy variable Common Law, which takes the value 1 for English common law countries and 0 for countries of all other legal traditions. Moreover, it is not clear what the distinctions between the civil law (Scandinavian, German and French) countries really mean. For instance, Nenova (2003) shows that the benefits from control are lower in countries with a Scandinavian civil law tradition than in common law countries while Coffee (2001) argues that social norms rather than legal regimes can explain these lower benefits of control. Small sample sizes of German and Scandinavian civil law countries also prevent us from making finer distinctions between the civil law countries. 
The data on religious composition is taken from LLSV (1999) to create the dummy variable Catholic Religion which takes the value 1 if Catholics are the dominant religious group in the country, and 0 if the dominant religious group in the country is Protestants or Muslims or Other Religions. Stulz and Williamson (2003) show that Catholic countries are particularly weak in creditor rights protection as well as the enforcement of shareholder rights, creditor rights, and property rights. We also use data on Ethnic Fractionalization from Alesina, et al (2003), which measures the probability that two randomly selected individuals from a country are from different ethnic groups.

To measure geographical endowments, we use Latitude, which is the absolute value of the latitude of the country scaled between 0 and 1, from LLSV (1999). Countries closer to the equator tend to have a more tropical climate that was inhospitable to European settlers and therefore may have fostered “extractive” institutions. Table 1 shows that the variable Latitude varies from 0 for Congo Democratic Republic which is located on the Equator and 0.01 for Kenya and Uganda (close to the equator) to 0.72 for Iceland.

Following Ayyagari, Demirguc-Kunt and Maksimovic (2005a), we construct quintiles of the continuous variables, Ethnic Fractionalization and Latitude to overcome non-linearities in the construction of the variables and use the discrete versions of the variables for the rest of our analysis. The search algorithm also works best with only continuous or discrete variables rather than with a mix of both types of variables.

Table 2 presents the summary statistics and correlation matrix between the variables. Panel B shows that Property Rights is highly correlated with Latitude, 
Common Law and Ethnic Fractionalization at the 1\% level but not correlated with the Catholic Religion variable.

\section{Determinants of property rights.}

The input to the TETRAD algorithm is a correlation (or covariance) matrix of the variables $^{6}$. One of the advantages of DAG analysis is that it allows us to incorporate prior knowledge about a temporal or causal ordering of the variables into the analysis. The algorithm uses the correlation matrix input along with the accompanying temporal restrictions and begins by assuming that all variables in the model are dependent, corresponding to the undirected graph in Figure 1. Under the assumption that the variables are jointly normally distributed, it then checks for conditional independence relations between the variables and depending on the relations found in the data, the edges between the variables are oriented.

We investigate three cases (a) When there is no temporal order assumed (b) Assuming a two-tier temporal order where property rights is identified as the dependent variable and (c) Three-tier temporal order where Tier 1 consists of Latitude, Tier 2 consists of Common Law, Catholic Religion, and Ethnic Fractionalization and Tier 3 consists of Property Rights. For each case we present the directed acyclic graphs at 1\%, $5 \%$ and $10 \%$ significance levels used for computing the significance of the correlation coefficients. Because the algorithm performs a complex sequence of statistical tests, each at the given significance level, the significance level is not an indication of error probabilities of the entire procedure. Spirtes, Glymour, and Sheines (1993) after exploring several versions of the algorithm on simulated data conclude that "in order for

\footnotetext{
${ }^{6}$ TETRAD also allows raw data as input. See the TETRAD III manual for further details.
} 
the method to converge to correct decisions with probability 1 , the significance level used in making decisions should decrease as the sample size increases, and the use of higher significance levels may improve performance at small sample sizes.”

\section{In the absence of any temporal ordering between the variables}

We start with the correlation matrix shown in Panel B of Table 2. The algorithm uses this input and starts with a complete undirected graph as shown in Figure 1. Assuming that the variables are jointly normally distributed, edges are now removed on the basis of vanishing correlations or partial (conditional) correlations.

When no temporal order is assumed and we let the data speak, Table 3 presents the conditional independence relations at the $5 \%$ significance level found in the data by the search algorithm. Table 3 shows that at the $5 \%$ level, Property Rights is independent of Catholic Religion and hence the edge between Property Rights and Catholic Religion is removed from the undirected graph in Figure 1. Further the correlations between Catholic Religion and Ethnic Fractionalization and Catholic Religion and Latitude are also not significant, leading to removal of the corresponding edges. When we look at the conditional correlations, conditional on Latitude, Common Law is independent of Ethnic Fractionalization leading to the removal of the direct edge between Common Law and Ethnic Fractionalization. The four independence relations shown in Table 3 are consistent with a specific causal structure represented by the DAG in Figure 2b. Figure 2b reveals that at the 5\% level, only Ethnic Fractionalization has a significant and direct impact on Property Rights protection. While Common Law and Latitude appear to be related to 
Property Rights the data is not sufficient to orient the edges between Common law and Property Rights and Latitude and Property Rights. ${ }^{7}$

When we repeat the analysis at the $1 \%$ and $10 \%$ significance levels, the independence relations ${ }^{8}$ are consistent with the causal structures shown in Figure 2a and Figure 2c. Figure 2a reveals that at the 1\% level, there is a relation between Property Rights and Ethnic Fractionalization (and none between Common Law or Latitude and Property Rights). However, the data by itself is not sufficient to orient the direction between the Ethnic Fractionalization and Property Rights consistent with any sensible theory of property rights. Figure 2c is identical to Figure $2 b$ revealing that the independence relations at the $10 \%$ significance level are the same as that in Table 3.

In the present case, there is theoretical justification for presuming that some historical factors like latitude are a prior determinant of property rights. Moreover, in the absence of further structure, it is not possible to make a suitable comparison between DAG and regression analysis or EBA. In the next section, we proceed by imposing a simple temporal order that is imposed in the regression framework.

\section{Two-Tier Temporal order}

In this section we impose the condition that the different institutional variablesCommon Law, Ethnic Fractionalization, Catholic Religion and Latitude affect Property

\footnotetext{
${ }^{7}$ Figure $2 \mathrm{~b}$ shows that the direction of orientation between Common Law and Property Rights (dotted line) is inconsistent, in that in some instances Common Law is a determinant of Property Rights and in other instances, Property Rights is a determinant of Common Law. The double headed arrow between Latitude and Property Rights shows that there may be a common latent factor driving the association between these two variables.

${ }^{8}$ There are six independence relations at the $1 \%$ level. The unconditional correlations reveal that Property Rights is independent of both Catholic religion and Common Law, Common Law is independent of Ethnic Fractionalization and Catholic Religion is independent of both Ethnic Fractionalization and Latitude are all insignificant at the $1 \%$ level. The conditional correlations reveal that conditional on Ethnic Fractionalization, Property Rights is independent of Latitude.
} 
Rights protection rather than the other way around. So we assume a two-tier temporal order where Tier 1 consists of the historical determinants of Property rights, Common Law, Latitude, Ethnic Fractionalization and Catholic Religion, and Tier 2 consists of the Property Rights variable itself. We do not make any a-priori assumptions about the temporal order among the Tier 1 variables.

Note that this assumption of temporal order is similar to the multiple regression framework when we have Property Rights as the dependent variable and Common Law, Ethnic Fractionalization, Latitude and Catholic Religion as the independent variables and where we do not explicitly allow for reverse causality. A key difference however, is that, although we specify a two tier order in DAG, a temporal order can emerge endogenously among the Tier 1 variables depending on the conditional correlations in the data. This is clearly not possible in classical regressions.

Knowledge of temporal precedence allows for limiting the number of tests for conditional independence and this can be very useful in reducing the run-time when we have several variables ${ }^{9}$. Temporal restrictions are implemented as forbidden edges. So in this case, since Property Rights is listed in a temporal tier after that of Common Law, the search algorithm will not consider models in which Property Rights Protection is a direct cause of Common Law. Similarly the program will not consider models in which Property Rights causes Latitude, Ethnic Fractionalization or Catholic Religion.

On running the search algorithm with the correlation matrix in Table 2 as an input with the temporal restriction specified above, we once again obtain the same set of

\footnotetext{
${ }^{9}$ In fact, Druzdel and Glymour (1995) argue that TETRAD II's algorithms are much more reliable in determining existence of direct causal links than in determining their orientation. Therefore, prior knowledge supplied to TETRAD II may be critical for the orientation of edges of the graph.
} 
conditional independence relations as in Table $3^{10}$. However, the Directed Acyclic Graph that is consistent with the conditional independence relations is quite different as shown in Figure 3. The process by which the unique patterns in Figure 3 are determined are described in detail for the 5\% significance level case (Figure 3b) in Appendix A2.

Figure 3b implies that at the 5\% level, Ethnic Fractionalization, Latitude and Common Law all have a direct causal effect on Property Rights. We now compare the set of conditional independence relations in panel A of Table 3 and the accompanying Figure 3b with the results from a classical multivariate regression as shown in Table 4 . We regress the Property Rights variable on all other variables-Common Law, Catholic Religion, Ethnic Fractionalization, and Latitude, entered one at a time in specifications (1) to (4) of Panel A in Table 4. In subsequent specifications, we try to analyze the relation between the regressors themselves by regressing each of the regressors on the other regressors.

Specifications (1) to (4) show that at the 5\% level, only Common Law, Latitude and Ethnic Fractionalization have significant coefficients in the Property Rights regression thus confirming the independence relations between Property Rights and Catholic Religion (independence relation I in Table 3). Specifications (5) to (7) reveal that Catholic Religion does not predict Latitude confirming the independence relation (III) in Table 3. Specifications (8) to (10) reveals that Catholic Religion also does not predict Ethnic Fractionalization at the 1\% level confirming independence relations (II) of Table 3. Specifications (11) to (16) provide further verification of the independence relations discussed above.

\footnotetext{
${ }^{10}$ This is to be expected since imposition of temporal order adds more structure to the analysis but does not change the existing independence relations present in the data.
} 
In Panel B of Table 4, we introduce control variables in the regressions to understand the conditional independence relations. For the purposes of this study, it is sufficient to illustrate the conditional independence relations with just the Property Rights regression. Panel B shows all possible combinations of the independent variables in the regression. For a variable to be identified as having a direct effect in DAG, this variable should have a significant coefficient in all regressions, with all combinations of the independent variables in the model. Already from specification (4) of Panel B, we can see that Catholic Religion does not have a direct causal effect on Property Rights at the $1 \%$ level since it does not have a significant coefficient. Specifications (5) to (10) in Panel B show that Common Law, Ethnic Fractionalization and Catholic Religion are significant at the $5 \%$ level regardless of which other regressors are entered in the model.

At the $1 \%$ level, panel A of Table 4 shows that only Latitude and Ethnic Fractionalization have significant coefficients in the Property Rights regression. However specification 5 of panel B rules out Latitude as having a direct effect since its coefficient is not significant at the $1 \%$ level when entered with Ethnic Fractionalization. At the $1 \%$ level, only Ethnic Fractionalization has a significant coefficient regardless of which other regressors are entered in the model; and Ethnic Fractionalization is also the only causal effect identified by DAG analysis in Figure 3a.

Thus Panels A and B have shown that the conditional independence relations identified by DAG analysis are supported by the partial correlations identified in the regression analysis. The differences between DAG and regression analysis can be seen at the $1 \%$ level where the DAG pattern in Figure 3a shows Ethnic Fractionalization to be the only significant direct cause of Property Rights, where as regression specifications in 
panel B of Table 4 mistakenly identify Ethnic Fractionalization, Latitude and Common Law as significant determinants.

We have also investigated alternative two-tier temporal order structures. For example, we can a priori assume that Latitude, being geographically determined, precedes all other institutional variables and therefore keep only Latitude in the first tier, while all other historical variables are included in the second tier with Property Rights. Doing so, at different significance levels, results in exactly the same graphs as in Figure 3.

In the following subsection, we investigate whether imposing further temporal conditions helps orient the indeterminate edges between the variables shown in Figure 3a.

\section{Three-Tier Temporal order}

Next, we impose a three-tier temporal order where Tier 1 consists of Latitude, Tier 2 consists of Common Law, Ethnic Fractionalization and Catholic Religion and Tier 3 consists of Property Rights. The temporal restrictions prevent Property Rights from affecting Latitude and Common Law, Ethnic Fractionalization and Catholic Religion and also prevent Latitude from being affected by Common Law, Ethnic Fractionalization and Catholic Religion. Note that the temporal order does not imply that Latitude cannot have a direct effect on Property Rights.

Following the input correlation matrix and the above temporal order, DAG analysis presents the same set of conditional relations shown in Table 3 and Figure 4.

Figure 4a again reveals that at the $1 \%$ level, Ethnic Fractionalization is the only variable that has a direct causal influence on Property Rights Protection and Common 
Law is independent of Property Rights Protection ${ }^{11}$. However at the 5\% significance level, Common Law, Ethnic Fractionalization and Latitude all have a direct causal influence on Property Rights. This exercise suggests that DAG results are quite stable regardless of the temporal order we impose.

\section{Robustness Tests}

In this section we present a number of robustness tests reported in Table 5. For the results in this table we use a significance level of 5 percent. However, as shown in Figure 3 using lower or higher significance levels does not change the result that Ethnic Fractionalization has a direct effect on Property Rights.

In Panel A, we investigate if our results are sensitive to sample composition. We first present results excluding countries with Socialist legal tradition, as Ayyagari, Demirguc-Kunt and Maksimovic (2005a) argue that these countries are fundamentally different from others in their perception of property rights protection. Next, we also drop African, and Latin American countries, respectively. Finally, we exclude Australia, Canada, New Zealand, and the United States from the sample, as these were settler colonies and their exclusion may impact the role Latitude plays in determining Property rights. The results in Panel A suggest that Ethnic Fractionalization continues to have a direct impact on Property Rights, regardless of sample composition and is the only variable to do so. The effect of Common Law legal tradition disappears when we drop Transition countries or Settler countries and the effect of Latitude disappears when we drop African countries or Settler countries.

\footnotetext{
${ }^{11}$ As already discussed above, a similar pattern is obtained if we go with a two-tier temporal order with Tier 1: Latitude and Tier 2: Ethnic Fractionalization, Religion, Legal Origin and Property Rights.
} 
In Panel B, we use an alternative variable to capture the endowment view, Good Crops. It is a measure of the extent to which the country's land is suitable to growing maize, wheat, rice and sugarcane ${ }^{12}$ and is expected to proxy for a country's historical agricultural endowments that affected historical institutions (Easterly and Levine (2003)). Indeed, when we replace Latitude by Good Crops, we see that Good Crops has a direct impact on Property Rights in the baseline specification. However, Good Crops is no longer a significant determinant of Property Rights when we drop African countries.

As an alternate measure of the endowment view, we use Settler Mortality in Panel C of Table 5. Settler Mortality is the log of the annualized deaths per thousand European soldiers in European colonies in the early $19^{\text {th }}$ century. Panel C shows that Settler Mortality is the most robust determinant of property rights protection lending support to the Endowments View. However these results must be interpreted with caution given the small sample sizes.

In unreported tables we also experimented with two other measures of fractionalization, Religious Fractionalization and Linguistic Fractionalization as defined in Alesina et al (2003). Neither of these two measures are found to significantly predict Property Rights protection. These results confirm that its ethnicity of the countries, where ethnicity is based on a combination of racial and linguistic differences, rather than purely linguistic or religious differences that explain Property Rights protection.

In Panel D, we explore an alternative measure of Property Rights protection used in the literature, Risk of Expropriation. The Risk of Expropriation index is the Political

\footnotetext{
${ }^{12}$ These are the main crops of focus since Engerman and Sokoloff (1997) argue that wheat and maize fostered a large middle class with egalitarian institutions where as rice and sugarcane produced a powerful elite and more closed institutions. Latitude has been the preferred proxy for the endowment view because it is more accurately measured and is available for a larger number of countries than either Good Crops or Settler Mortality.
} 
Risk Services' assessment of the protection against government expropriation in the country and is scaled $0-10$, where higher scores mean less risk of expropriation of private foreign investment by the government. Using these variables instead of the Property Rights variable does not alter our main results. Ethnic Fractionalization still has a direct effect on the dependent variable except when we drop African countries when Latitude has a direct effect on Property Rights protection.

Acemoglu and Johnson (2006) distinguish between determinants of property rights institutions and contracting institutions, and suggest that while the endowment view determines property rights, legal origin determines contract enforcement. In Panel E, we use the three contract enforcement variables used in their study to see if we also observe these differences - Legal formalism from Djankov et al. (2003) measures the number of formal legal procedures necessary to resolve the simple disputes of collecting on an unpaid check or evicting a non-paying tenant; Number of Procedures is the number of formal procedures involved in registering a new business; and Procedural complexity is an index varying between 0 and 100 where higher values indicate more complexity in contract enforcement procedures. Number of Procedures and Procedural Complexity are from the World Bank’s Doing Business database.

Our results provide some support for their findings. Common Law, not Ethnic Fractionalization or Latitude has a direct effect on Legal Formalism and Procedural Complexity. However, in the case of Procedural Complexity, Catholic Religion also enters with a direct effect. Finally, when we focus on Number of Procedures, it is both Ethnic Fractionalization and Common Law, that have a direct effect. Thus, if we were to 
look at Contract Enforcement as opposed to Property Rights protection, Legal Origin has the greatest support, followed by Ethnic Fractionalization, and then Religion.

In panel F of Table 5, we randomly sample 100 countries and perform 100 trials so that in each trial, the set of 100 countries sampled is different. We then report the frequency with which each institutional theory is found to be the most dominant predictor of Property Rights. Panel F shows that when we randomly sample 100 countries 100 times, the variable with the highest probability of explaining Property Rights is Ethnic Fractionalization. Ethnic Fractionalization is the sole dominant explanatory variable in $34 \%$ of the cases followed by Latitude in $14 \%$ of the cases. Common Law and Catholic Religion are never the only determinants of Property Rights and always occur in conjunction with Ethnic Fractionalization or Latitude

\section{Comparing DAG to Extreme Bounds Analysis}

DAG analysis also has similarities to Extreme Bounds Analysis (EBA) described in Leamer (1983) and subsequently used by Levine and Renelt (1992) and Kormendi and Meguire (1985). EBA is designed to test the robustness of coefficient estimates to alterations in the conditioning information set, in order to be able to estimate the confidence one can place in the conclusions of the cross-country regressions. In EBA, the relationship between property rights protection and a particular variable of interest is considered to be robust only if the coefficient remains statistically significant and of the theoretically predicted sign when the conditioning variable sets are changed in the regressions. So EBA would help us understand if the partial correlations established in the regression analysis are robust or fragile to small changes in the set of right hand side 
variables used in the regression. In this aspect it is similar to DAG since it uses the conditioning information set to determine the robustness of a particular variable. However, EBA looks at one coefficient at a time and the conditioning information set is restricted to triads of variables. DAG on the other hand allows us to examine the conditional independence relationships between all variables simultaneously and in addition shows us the direct and indirect effects of each of the variables ${ }^{13}$.

Specifically, suppose we are interested in knowing whether a variable $\mathrm{Z}$ is robust in predicting property rights protection, we estimate regressions of the form:

Property Rights $=\mathrm{a}+\mathrm{b}_{\mathrm{z}} \mathrm{Z}+\mathrm{b}_{\mathrm{xj}} \mathrm{X}_{\mathrm{j}}+\mathrm{e}$

where $\mathrm{x}_{\mathrm{j}} \in \mathrm{X}$ is a vector of up to three variables taken from the pool $\mathrm{X}$ of $\mathrm{N}$ variables. The regression is estimated for all $\mathrm{M}$ possible combinations of $\mathrm{x}_{\mathrm{j}} \in \mathrm{X}$ and for each model $\mathrm{j}$, the estimate $\mathrm{b}_{\mathrm{zj}}$ and the corresponding standard deviation $\mathrm{s}_{\mathrm{zj}}$ are identified. At the 5\% level at which EBA is performed in the Levine and Renelt study, the lower extreme bound is the lowest value of $b_{z j}-2 s_{z j}$ and the upper extreme bound is the largest value of $b_{z j}+2 s_{z j}$. According to EBA, variable $z$ is robust only if both bounds are of the same sign. The extreme bounds consistent with a $1 \%$ significance level are $b_{\mathrm{zj}}-3 \mathrm{~s}_{\mathrm{zj}}$ (lower extreme bound) and $b_{z j}+3 s_{z j}$ (upper extreme bound).

However, Sala-i-Martin (1997) points out that the extreme bounds test is too strict a test especially in the presence of multicollinearity. Instead, he suggests that rather than focusing on extreme bounds, one should focus on the entire distribution of the estimators, specifically the fraction of the cumulative distribution lying on each side of zero, CDF (0). If CDF (0) is $>0.95$, then the variable is considered to be robust. The cumulative

\footnotetext{
${ }^{13}$ EBA may be considered to be a parameter estimation analysis where as DAG is a model specification analysis.
} 
distribution function itself is calculated from the weighted mean and weighted standard deviation of the parameter with the integrated likelihood of each model being used as weights. So under the assumption that the distribution of the estimates of $b_{z}$ across models is normal, for each of the M models, we compute the integrated likelihood $L_{j}$. From this, the weighted mean and weighted standard deviation, which are used as parameters in the cumulative distribution function, are calculated where the weights used are proportional to the integrated likelihoods. See Sala-i-Martin (1997) for more details.

Table 6 replicates our analysis using EBA and the Sala-i-Martin (1997) specification for Latitude and Ethnic Fractionalization, which are the only two variables found to be significant in predicting Property Rights when used by themselves. Panels A1 and A2 present the extreme bounds for the variable at the $5 \%$ significance level $\left(b_{z j} \pm 2 s_{z j}\right)$ and $1 \%$ significance levels $\left(\mathrm{b}_{\mathrm{zj}} \pm 3 \mathrm{~s}_{\mathrm{zj}}\right.$ ) respectively and the corresponding conditioning information set.

At the 5\% level, the extreme lower bound for Ethnic Fractionalization is -0.447 (and significant) and is attained when we include Common Law along with Ethnic Fractionalization in the Property Rights regression. The upper extreme bound for Ethnic Fractionalization is -0.031 (and significant) and is attained when we include both Latitude and Catholic Religion along with Ethnic Fractionalization in the Property Rights regression. The two extreme bounds for Ethnic Fractionalization are of the same sign and are significant indicating that Ethnic Fractionalization is a robust predictor of Property Rights, robust to any changes in the conditioning information set. A similar analysis for Latitude and Common Law, the only other variables that were significant in the property rights regression reveals that the lower and upper extreme bounds for both variables are 
of the same signs confirming our previous results in Figure 3b, that at the 5\% level, Ethnic Fractionalization, Common Law and Latitude are robust predictors of property rights.

Panel A2 presents EBA analysis at the 1\% level for Ethnic Fractionalization and Latitude, which are the only variables significant in the property rights regression at the 1\% level to start with. EBA analysis at the 1\% level reveals that both Latitude and Ethnic Fractionalization are not robust predictors since the upper extreme bound in the case of Ethnic Fractionalization (t-stat $=-2.42$ ) and the lower extreme bound in the case of Latitude $(\mathrm{t}$-state $=2.37)$ are not significant at the $1 \%$ level.

The EBA analysis in Panel A2 can be reconciled with the DAG analysis in Figure 3a by noting that in the case of Ethnic Fractionalization the insignificant upper extreme bound (at the 1\% level) involves Catholic Religion in the conditioning information set. Catholic Religion is insignificant (unconditional correlation) when entered alone in the Property Rights Regression and hence in the case of DAG analysis does not play a part in computing conditional correlations. If we were to impose the same criterion for EBA and remove all instances where Catholic Religion is part of the conditioning information set, we find that Ethnic Fractionalization is the only robust predictor of property rights ${ }^{14}$.

Panel B presents results from application of the Sala-i-Martin (1997) methodology. As expected, this method is less strict in picking out the most robust predictor and therefore cannot distinguish as well among different historical determinants. At the 5\% level, Latitude, Common Law and Ethnic Fractionalization have

\footnotetext{
${ }^{14}$ In this case at the $1 \%$ level, the upper extreme bound for Ethnic Fractionalization is 0.027 with a t-stat=2.63 and is achieved when the conditioning information set includes only Latitude. The lower extreme bound is -0.509 with a t-stat $=-5.22$ for a conditioning information set that consists of Common Law.
} 
CDF (0) $>0.95^{15}$ indicating they are robust predictors of Property Rights. The same holds for the $1 \%$ level. While this method is less able to distinguish between the different theories it is important to note that even in this method, Ethnic Fractionalization is a robust predictor of Property Rights protection.

\section{Monte Carlo Simulations}

In this section, we use Monte Carlo simulations to test the reliability of the model obtained by DAG analysis. Since the models obtained through DAG analysis are the results of an automated search procedure, accounting for the potential errors associated with the search itself is important. One of the drawbacks of hypothesis testing in any algorithm based approach such as TETRAD is that error probabilities of the search procedures are almost impossible to determine. This is because the p- level of a test is not directly related to the probability of error in a search procedure that involves testing a series of hypothesis. If, for example, for each pair of a set of variables, hypotheses of independence are tested at $\mathrm{p}=0.05$, then 0.05 is not the probability of erroneously finding some dependent set of variables when in fact all pairs are independent.

However, simulation methods can be used to reliably test for the error probabilities associated with the outcome search. Specifically, given the model in Figure 3a from a sample of 158 countries, we first estimate the model and then use the estimated model to generate a number of samples of varying sizes. We then run the search procedure on each sample and calculate the frequency with which the relation we are interested in, Ethnic Fractionalization $\rightarrow$ Property Rights, is incorrect in the output.

\footnotetext{
${ }^{15}$ Note that in keeping with the convention in Sala-i-Martin (1997), CDF (0) is that larger of the two areas under the density curve when divided by zero. So it could be either $\operatorname{CDF}(0)$ or 1-CDF(0) and is therefore always a number between 0.5 and 1
} 
Alternatively, we can generate a hypothetical model M' where say in addition to Ethnic Fractionalization $\rightarrow$ Property Rights, Common Law $\rightarrow$ Property Rights and Latitude $\rightarrow$ Property Rights. We estimate M' and use $\mathrm{M}^{\prime}$ to generate a number of samples of size n, run the search procedure on sample and calculate the frequency with which we only find Ethnic Fractionalization $\rightarrow$ Property Rights (and not Common $\rightarrow$ Property Rights or Latitude $\rightarrow$ Property Rights) in the output. For all the simulations we generate 100 samples at five different sample sizes, 50, 100, 150, 200 and 250.

Table 9 presents the results from the Monte Carlo simulations performed on 2000 randomly generated datasets. In Panel A, the simulations were carried out on a model similar to Figure 3a imposing the 2-Tier temporal order where Tier 1 consists of Latitude, Common Law, Catholic Religion and Ethnic Fractionalization and Tier 2 consists of Property Rights. The significance levels at which the tests were carried out were $5 \%$ and $1 \%$. The number in each cell presents the frequency with which we don't find Ethnic Fractionalization $\rightarrow$ Property Rights. At the 5\% level, the results show that at sample sizes above 100, Ethnic Fractionalization is found to be a strong predictor of Property Rights protection. In aggregate, out of 1000 randomly generated datasets, the hypothesis is rejected only $3 \%$ of the time. Note that these results correspond to finding the frequency of Type I error of the algorithm which is the probability of rejecting the null hypothesis when it is true.

To investigate the power of the algorithm against alternate models, we consider a modification of the model in figure 2c where we add the edges Common Law $\rightarrow$ Property Rights and Latitude $\rightarrow$ Property Rights. We generate 100 samples at each of the five sample sizes $(50,100,150,200,250)$. Panel B shows that at sample sizes of 50 , in $6 \%$ of 
the cases we only find Ethnic Fractionalization $\rightarrow$ Property Rights and not Common Law $\rightarrow$ Property Rights or Latitude $\rightarrow$ Property Rights or both but this reduces to $0 \%$ at larger sample sizes of 100 or more observations. This holds for both $5 \%$ and $1 \%$ level of significance at which the conditional correlation tests are conducted. In other words, the results in Panel B show that the probability of a Type II error (probability of not rejecting the null hypothesis when an alternative is true) is very small at sample sizes of 100 or more observations. The results thus show that the tests have high power ${ }^{16}$ in making a correct decision and the algorithm is sufficiently reliable in detecting alternate causal influences if they are strong.

\section{Conclusion}

Using cross-country data, this paper evaluates historical determinants of protection of property rights. We examine four historical theories that focus on different distinct causal mechanisms in shaping institutions, as captured by legal origin, endowments, ethnic diversity and religion. We use Directed Acyclic Graph (DAG) methodology to identify which historical factors are direct determinants of property rights protection and which are not, and illustrate how regression-based analyses can lead to misleading results. The empirical results support only the ethnic fractionalization view as a determinant of property rights protection. These results are robust to DAG model specification, sample composition include random sample sorts, use of alternative proxies for Endowment views, and different definitions of property rights protection. We also compare our analysis to Extreme Bounds Analysis and get similar results.

\footnotetext{
${ }^{16}$ Note that Power of a test measures the test's ability to reject the null hypothesis when it is actually false, ie the probability of not committing a Type II error. In our case, the power of the test ranges from $94 \%$ (1$\beta=1-0.06)$ to $100 \%(1-0.00)$
} 
Despite the attention it has received in the literature, support in the data for the proposition that legal origin is a significant determinant of the protection of property rights is fragile and is dependent on the inclusion of transition economies in the sample. 


\section{References}

Acemoglu, D., Johnson, S., 2006. Unbundling Institutions. Journal of Political Economy forthcoming.

Acemoglu, D., Johnson, S., and Robinson, J. A., 2001, The Colonial Origins of Comparative Development: An Empirical Investigation. American Economic Review 91, 1369-1401.

Alesina, A., Devleeschauwer, A., Easterly, W., Kurlat, S., Wacziarg, R., 2003. Fractionalization. Journal of Economic Growth 8(2).

Ayyagari, M., Demirgüç-Kunt, A., Maksimovic, V., 2005a. How Well do Institutional Theories Explain Firms’ Perceptions of Property Rights Protection? World Bank mimeo.

Ayyagari, M., Demirgüç-Kunt, A., Maksimovic, V., 2005b. How Important Are Financing Constraints? The role of finance in the business environment. World Bank mimeo.

Barro, R. J., 1991. Economic Growth in a Cross Section of Countries. Quarterly Journal of Economics 106: 407-443

Beck, T., Demirgüç-Kunt, A., Levine, R., 2003. Law, Endowments, and Finance. Journal of Financial Economics 70 (2), 137-181.

Beck, T., Demirgüç-Kunt, A., Maksimovic, V., 2005. Financial and Legal Constraints to Firm Growth: Does Firm Size Matter. Journal of Finance 60, 137-179.

Black, F., 1993. Estimated expected returns. Financial Analysts Journal, 36-38.

Claessens, S., Laeven, L., 2003. Financial Development, Property Rights and Growth. Journal of Finance Vol. LV111, No. 6, 2401-2436.

Coffee, J. C., 2001, Do norms matter? A cross-country examination of the private benefits of control, unpublished working paper, Columbia Law School, Columbia, New York, NY.

Djankov, S., La Porta, R., Lopez-de-Silanes, F., Shleifer, A., 2003. Courts. Quarterly Journal of Economics, 118 (2), 453-517.

Druzdel, M.J., Glymour, C., 1995. What do college ranking data tell us about student retention: Causal discovery in Action. In Proceedings of the Fourth International Workshop on Intelligent Information Systems, Poland, 138-147.

Easterly, W., Levine, R., 1997. Africa’s growth tragedy: policies and ethnic divisions. Quarterly Journal of Economics 112, 1203-1250. 
Easterly, W., Levine, R., 2003. Tropics, germs and crops: the role of endowments in economic development. Journal of Monetary Economics 50 (1).

Engerman, S., Sokoloff, K., 1997. Factor endowments, institutions, and differential paths of growth among new world economies. In Haber, S.H. (Ed.), How Latin America Fell Behind, Stanford University Press, Stanford CA, pp. 260-304.

Foster, D.F., Smith, T., Whaley, R. E., 1997. Assessing Goodness-of-Fit of Asset Pricing Models: The Distribution of the Maximal R², Journal of Finance 52(2), 591-607.

Hayek, F., 1960. The Constitution of Liberty. The University of Chicago Press, Chicago, IL.

Johnson, S., Kaufmann, D., Zoido-Lobaton, P., 1998. Government in transition:

Regulatory discretion and the unofficial economy, American Economic Review 88, 387392.

Kormendi, R.C., Meguire, P.G., 1985. Macroeconomic Determinants of Growth: CrossCountry Evidence. Journal of Monetary Economics 16, 141-163.

La Porta, R., Lopez-de-Silanes, F., Shleifer, A., Vishny, R.W., 1998. Law and finance. Journal of Political Economy 106, 1113-1155

La Porta, R., Lopez-de-Silanes, F., Shleifer, A., Vishny, R.W., 1999. The Quality of Government. Journal of Law, Economics, and Organization 15, 222-279.

La Porta, R., Lopez-de-Silanes, F., Pop-Eleches, C., Shleifer, A., 2002. The Guarantees of Freedom. Mimeo, Harvard University.

Landes, D., 1998. The Wealth and Poverty of Nations. Little, Brown, and Company, London.

Leamer, E. E., 1978, Specification Searches, Wiley, New York.

Leamer, E.E., 1983. Let's Take the Con Out of Econometrics. American Economic Review 73, 31-43.

Levine, R., Renelt, D., 1992. A Sensitivity Analysis of Cross-Country Growth Regressions. American Economic Review 82(4), 942-963.

Lo, A., MacKinlay, A. C., 1990. Data-snooping biases in tests of financial asset pricing models, The Review of Financial Studies 3, 431-467.

Lo, A., MacKinlay, A.C., 1997. Maximizing Predictability in the Stock and Bond Markets, Macroeconomoc Dynamics 1, 118-158. 
Mahoney, P.G., 2001. The Common Law and Economic Growth: Hayek Might be Right. Journal of Legal Studies 30, 503-25.

Merryman, J.H., 1985. The Civil Law Tradition: An Introduction to the Legal Systems of Western Europe and Latin America. Stanford University Press, Stanford, CA.

Merton, R., 1987. On the current state of the stock market rationality hypothesis in R. Dornbusch, S. Fisher, and J. Bossons, Eds: Macroeconomics and Finance: Essays in Honor of Franco Modigliani (M.I.T Press, Cambridge)

Nenova, T., 2003. The value of corporate voting rights and control: A cross-country analysis, Journal of Financial Economics 68(3). 325-351.

Pearl, J.,1988. Probabilistic Reasoning in Intelligent Systems. Morgan and Kaufman, San Mateo, CA.

Putnam, R., 1993. Making Democracy Work. Civic Traditions in Modern Italy. Princeton University Press, Princeton.

Sala-i-Martin, X. 1997. I Just Ran Two Million Regressions. American Economic Review 87 (2), 178-183.

Scheines, R., 2001. Estimating Latent Causal Influences: TETRAD III Variable Selection and Bayesian Parameter Estimation

Spirtes, P., Glymour, C., Scheines, R., 1993. Causation, Prediction and Search, New York: Springer-Verlag.

Spirtes, P., Glymour, C., Scheines, R., 2000. Causation, Prediction and Search $2^{\text {nd }}$ Edition. MIT Press, Cambridge, MA

Stulz, R., Williamson, R. 2003. Culture, Openness and Finance. Journal of Finance 70 (3), 313-49. 


\section{Figures: Directed Acyclic Graphs}

The following set of figures show graphical relations between different set of variables derived from the unconditional and conditional correlations. A single headed arrow between variables A and B with the arrowhead at B implies A causes B. A double headed arrow between variables A and B implies an inconsistent direction of orientation (causation) between the two variables and a dotted line between A and B implies a common latent factor could be driving the correlations between the two variables. A and B could be Property Rights, Common Law Dummy, Latitude, Ethnic Fractionalization or Catholic Religion. Property Rights, scored from 1 to 5, reflects the degree to which government enforces laws that protect private property, with higher numbers indicating bette enforcement. Common Law Dummy takes the value 1 for Common Law countries and 0 otherwise. Catholic Religion takes the value 1 if Catholics are the dominant religious group in the country and 0 if it is some other religious group. Ethnic Fractionalization is the probability that two randomly selected individuals in a country do not belong to the same ethnic group. Ethnic Fractionalization (quintiles) takes values 1 to 5 according to the four quintiles of ethnic fractionalization. Latitude is the absolute value of the latitude of the country scaled between zero and one. Latitude (quintiles) takes

values 1 to 5 according to the four quintiles of the latitude variable. Property Rights are from the Heritage Foundation for the year 2000.

\section{Figure 1: Undirected Graph showing all possible dependencies between the variables}

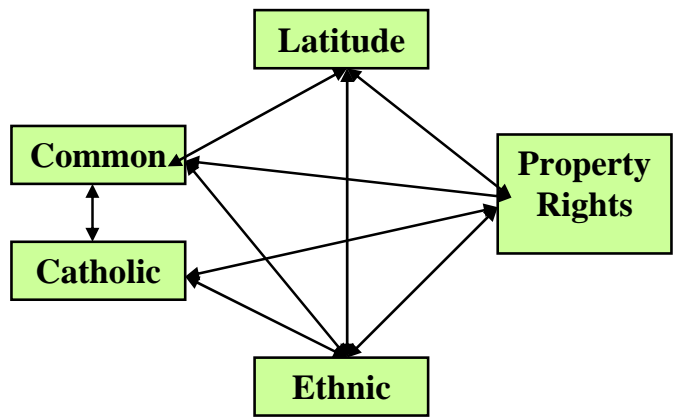

Figure 2: Directed Acyclic Graphs - Assuming no temporal order

2A: 1\% Significance Level

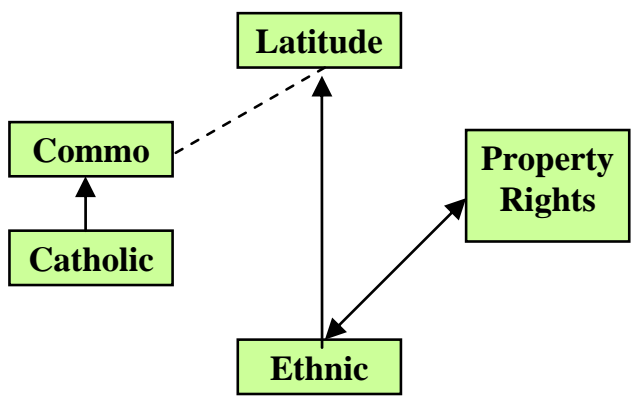

2B: 5\% Significance Level

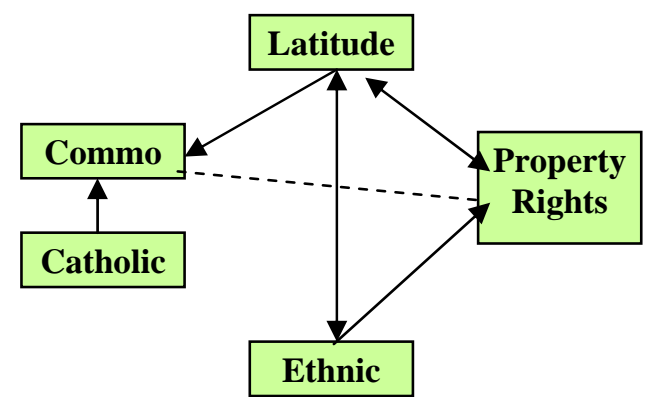

2B: $10 \%$ Significance Level

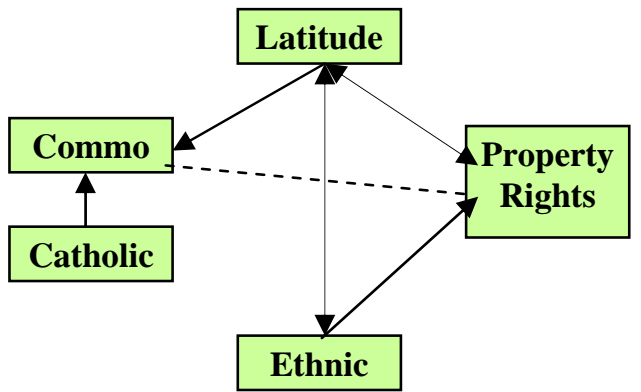


Figure 3: Directed Acyclic Graphs - Assuming 2-Tier temporal order

Tier 1: Latitude, Ethnic Fractionalization, Common Law, Catholic Religion

Tier 2: Property Rights

3A: 1\% Significance Level

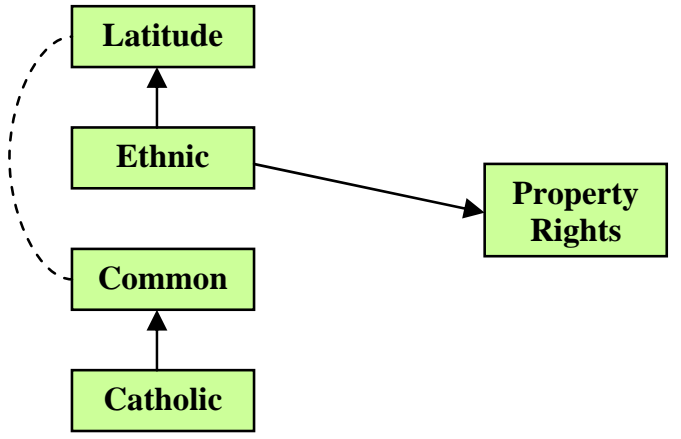

\section{B: 5\% Significance Level}

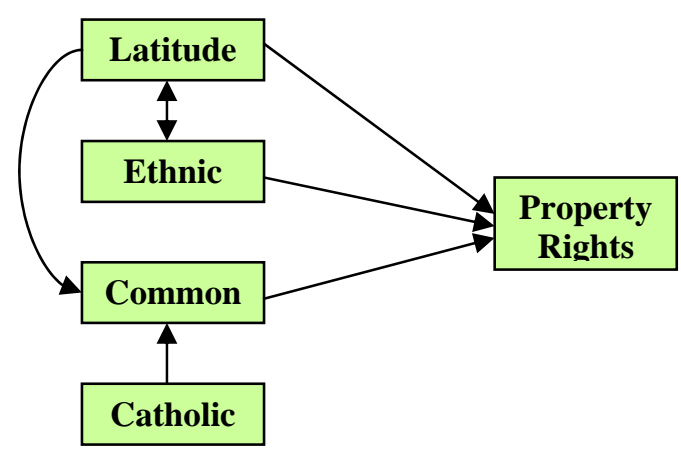

3B: 10\% Significance Level

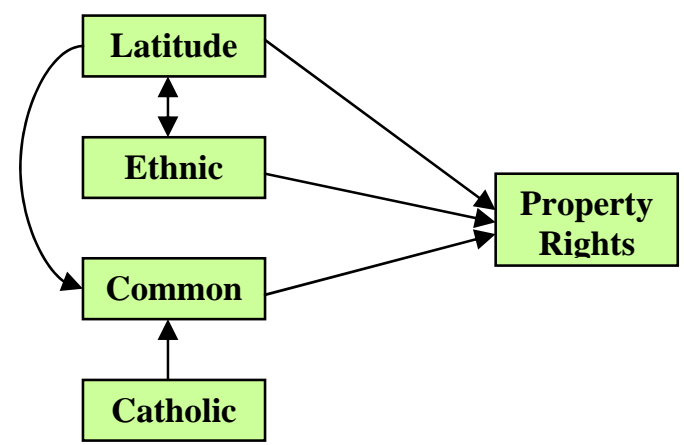

Figure 4: Directed Acyclic Graphs - Assuming 3-Tier temporal order

Tier 1: Latitude

Tier 2: Ethnic Fractionalization, Common Law, Catholic Religion

Tier 3: Property Rights

4A: 1\% Significance Level

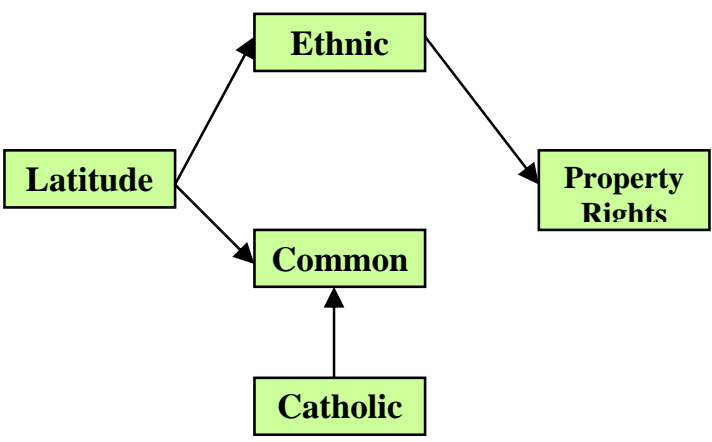

4B: 5\% Significance Level

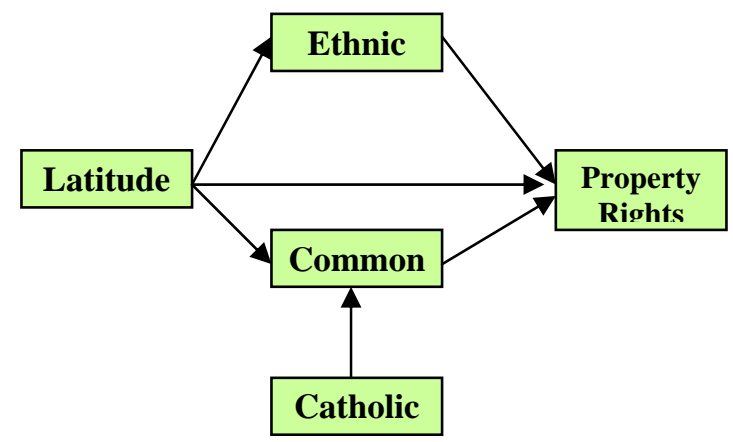

4B: $10 \%$ Significance Level

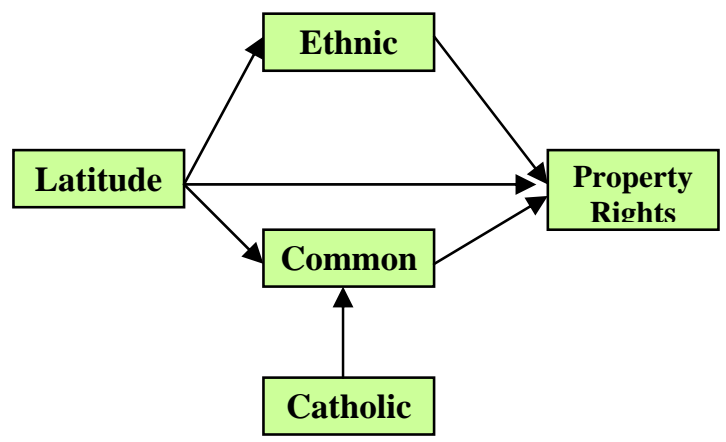




\section{Table 1: Descriptive Statistics}

Property Rights, scored from 1 to 5, reflects the degree to which government enforces laws that protect private property, with higher numbers indicating better enforcement. Common Law Dummy takes the value 1 for Common Law countries and 0 otherwise. Catholic Religion takes the value 1 if Catholics are the dominant religious group in the country and 0 if it is some other religious group. Ethnic Fractionalization is the probability that two randomly selected individuals in a country do not belong to the same ethnic group. Ethnic Fractionalization (quintiles) takes values 1 to 5 according to the four quintiles of ethnic fractionalization. Latitude is the absolute value of the latitude of the country scaled between zero and one. Latitude (quintiles) takes values 1 to 5 according to the four quintiles of the latitude variable. Property Rights are from the Heritage Foundation for the year 2000.

\begin{tabular}{|c|c|c|c|c|c|c|c|}
\hline Nation & $\begin{array}{c}\text { Property } \\
\text { Rights }\end{array}$ & $\begin{array}{c}\text { Common } \\
\text { Law }\end{array}$ & $\begin{array}{l}\text { Catholic } \\
\text { Religion }\end{array}$ & $\begin{array}{c}\text { Ethnic } \\
\text { Fractionalization }\end{array}$ & $\begin{array}{c}\text { Ethnic } \\
\text { Fractionalization } \\
\text { (quintiles) }\end{array}$ & Latitude & $\begin{array}{c}\text { Latitude } \\
\text { (quintiles) }\end{array}$ \\
\hline Albania & 2 & 0 & 0 & 0.2204 & 2 & 0.4556 & 4 \\
\hline Algeria & 3 & 0 & 0 & 0.3394 & 2 & 0.3111 & 3 \\
\hline Angola & 2 & 0 & 1 & 0.7867 & 5 & 0.1367 & 2 \\
\hline Argentina & 4 & 0 & 1 & 0.255 & 2 & 0.3778 & 4 \\
\hline Armenia & 3 & 0 & 0 & 0.1272 & 1 & 0.4444 & 4 \\
\hline Australia & 5 & 1 & 0 & 0.0929 & 1 & 0.3000 & 3 \\
\hline Austria & 5 & 0 & 1 & 0.1068 & 1 & 0.5244 & 5 \\
\hline Azerbaijan & 2 & 0 & 0 & 0.2047 & 2 & 0.4478 & 4 \\
\hline Bahamas, The & 5 & 1 & 0 & 0.4228 & 3 & 0.2683 & 3 \\
\hline Bahrain & 5 & 1 & 0 & 0.5021 & 3 & 0.2889 & 3 \\
\hline Bangladesh & 2 & 1 & 0 & 0.0454 & 1 & 0.2667 & 3 \\
\hline Barbados & 4 & 1 & 0 & 0.1423 & 1 & 0.1456 & 2 \\
\hline Belarus & 2 & 0 & 0 & 0.3222 & 2 & 0.5889 & 5 \\
\hline Belgium & 5 & 0 & 1 & 0.5554 & 4 & 0.5611 & 5 \\
\hline Belize & 3 & 1 & 1 & 0.7015 & 4 & 0.1906 & 2 \\
\hline Benin & 3 & 0 & 0 & 0.7872 & 5 & 0.1033 & 1 \\
\hline Bolivia & 3 & 0 & 1 & 0.7396 & 5 & 0.1889 & 2 \\
\hline Bosnia and Herzegovina & 1 & 0 & 0 & 0.63 & 4 & 0.4889 & 4 \\
\hline Botswana & 4 & 1 & 0 & 0.4102 & 3 & 0.2444 & 3 \\
\hline Brazil & 3 & 0 & 1 & 0.5408 & 4 & 0.1111 & 1 \\
\hline Bulgaria & 3 & 0 & 0 & 0.4021 & 3 & 0.4778 & 4 \\
\hline Burkina Faso & 3 & 0 & 0 & 0.7377 & 5 & 0.1444 & 2 \\
\hline Burundi & 2 & 0 & 1 & 0.2951 & 2 & 0.0367 & 1 \\
\hline Cambodia & 2 & 0 & 0 & 0.2105 & 2 & 0.1444 & 2 \\
\hline Cameroon & 2 & 0 & 1 & 0.8635 & 5 & 0.0667 & 1 \\
\hline Canada & 5 & 1 & 1 & 0.7124 & 5 & 0.6667 & 5 \\
\hline Cape Verde & 4 & 0 & 1 & 0.4174 & 3 & 0.1778 & 2 \\
\hline Chad & 2 & 0 & 0 & 0.862 & 5 & 0.1667 & 2 \\
\hline Chile & 5 & 0 & 1 & 0.1861 & 2 & 0.3333 & 3 \\
\hline China & 2 & 0 & 0 & 0.1538 & 1 & 0.3889 & 4 \\
\hline Colombia & 3 & 0 & 1 & 0.6014 & 4 & 0.0444 & 1 \\
\hline Congo, Dem. Rep. & 1 & 0 & 1 & 0.8747 & 5 & 0.0000 & 1 \\
\hline Congo, Rep. & 2 & 0 & 1 & 0.8747 & 5 & 0.0111 & 1 \\
\hline Costa Rica & 3 & 0 & 1 & 0.2368 & 2 & 0.1111 & 1 \\
\hline Croatia & 2 & 0 & 1 & 0.369 & 3 & 0.5011 & 5 \\
\hline Cuba & 1 & 0 & 0 & 0.5908 & 4 & 0.2367 & 3 \\
\hline Cyprus & 4 & 1 & 0 & 0.0939 & 1 & 0.3889 & 4 \\
\hline Czech Republic & 4 & 0 & 0 & 0.3222 & 2 & 0.5494 & 5 \\
\hline Denmark & 5 & 0 & 0 & 0.0819 & 1 & 0.6222 & 5 \\
\hline Djibouti & 3 & 0 & 0 & 0.7962 & 5 & 0.1256 & 2 \\
\hline Dominican Republic & 2 & 0 & 1 & 0.4294 & 3 & 0.2111 & 2 \\
\hline Ecuador & 3 & 0 & 1 & 0.655 & 4 & 0.0222 & 1 \\
\hline Egypt, Arab Rep. & 3 & 0 & 0 & 0.1836 & 2 & 0.3000 & 3 \\
\hline El Salvador & 4 & 0 & 1 & 0.1978 & 2 & 0.1500 & 2 \\
\hline Equatorial Guinea & 1 & 0 & 1 & 0.3467 & 2 & 0.0222 & 1 \\
\hline Estonia & 4 & 0 & 0 & 0.5062 & 3 & 0.6556 & 5 \\
\hline Ethiopia & 2 & 1 & 0 & 0.7235 & 5 & 0.0889 & 1 \\
\hline Fiji & 3 & 1 & 0 & 0.5479 & 4 & 0.2000 & 2 \\
\hline Finland & 5 & 0 & 0 & 0.1315 & 1 & 0.7111 & 5 \\
\hline France & 4 & 0 & 1 & 0.1032 & 1 & 0.5111 & 5 \\
\hline Gabon & 3 & 0 & 1 & 0.769 & 5 & 0.0111 & 1 \\
\hline Gambia, The & 3 & 1 & 0 & 0.7864 & 5 & 0.1476 & 2 \\
\hline
\end{tabular}




\begin{tabular}{|c|c|c|c|c|c|c|c|}
\hline Nation & $\begin{array}{l}\text { Property } \\
\text { Rights }\end{array}$ & $\begin{array}{c}\text { Common } \\
\text { Law }\end{array}$ & $\begin{array}{l}\text { Catholic } \\
\text { Religion }\end{array}$ & $\begin{array}{l}\text { Ethnic } \\
\text { Fractionalization }\end{array}$ & $\begin{array}{c}\text { Ethnic } \\
\text { Fractionalization } \\
\text { (quintiles) }\end{array}$ & Latitude & $\begin{array}{c}\text { Latitude } \\
\text { (quintiles) }\end{array}$ \\
\hline Georgia & 2 & 0 & 0 & 0.4923 & 3 & 0.4667 & 4 \\
\hline Germany & 5 & 0 & 0 & 0.1682 & 1 & 0.5667 & 5 \\
\hline Ghana & 3 & 1 & 0 & 0.6733 & 4 & 0.0889 & 1 \\
\hline Greece & 4 & 0 & 0 & 0.1576 & 1 & 0.4333 & 4 \\
\hline Guatemala & 3 & 0 & 1 & 0.5122 & 3 & 0.1700 & 2 \\
\hline Guinea & 2 & 0 & 0 & 0.7389 & 5 & 0.1222 & 1 \\
\hline Guinea-Bissau & 1 & 0 & 0 & 0.8082 & 5 & 0.1333 & 2 \\
\hline Guyana & 3 & 1 & 0 & 0.6195 & 4 & 0.0556 & 1 \\
\hline Haiti & 1 & 0 & 1 & 0.095 & 1 & 0.2111 & 2 \\
\hline Honduras & 3 & 0 & 1 & 0.1867 & 2 & 0.1667 & 2 \\
\hline Hong Kong, China & 5 & 1 & 0 & 0.062 & 1 & 0.2461 & 3 \\
\hline Hungary & 4 & 0 & 1 & 0.1522 & 1 & 0.5222 & 5 \\
\hline Iceland & 5 & 0 & 0 & 0.0798 & 1 & 0.7222 & 5 \\
\hline India & 3 & 1 & 0 & 0.4182 & 3 & 0.2222 & 2 \\
\hline Indonesia & 3 & 0 & 0 & 0.7351 & 5 & 0.0556 & 1 \\
\hline Iran, Islamic Rep. & 1 & 1 & 0 & 0.6684 & 4 & 0.3556 & 4 \\
\hline Iraq & 1 & 0 & 0 & 0.3689 & 2 & 0.3667 & 4 \\
\hline Ireland & 5 & 1 & 1 & 0.1206 & 1 & 0.5889 & 5 \\
\hline Israel & 4 & 1 & 0 & 0.3436 & 2 & 0.3478 & 4 \\
\hline Italy & 4 & 0 & 1 & 0.1145 & 1 & 0.4722 & 4 \\
\hline Jamaica & 4 & 1 & 0 & 0.4129 & 3 & 0.2017 & 2 \\
\hline Japan & 5 & 0 & 0 & 0.0119 & 1 & 0.4000 & 4 \\
\hline Jordan & 4 & 0 & 0 & 0.5926 & 4 & 0.3444 & 3 \\
\hline Kazakhstan & 2 & 0 & 0 & 0.6171 & 4 & 0.5333 & 5 \\
\hline Kenya & 3 & 1 & 0 & 0.8588 & 5 & 0.0111 & 1 \\
\hline Korea, Dem. Rep. & 1 & 0 & 0 & 0.0392 & 1 & 0.4444 & 4 \\
\hline Korea, Rep. & 5 & 0 & 0 & 0.002 & 1 & 0.4111 & 4 \\
\hline Kuwait & 5 & 0 & 0 & 0.6604 & 4 & 0.3256 & 3 \\
\hline Kyrgyz Republic & 2 & 0 & 0 & 0.6752 & 4 & 0.4556 & 4 \\
\hline Latvia & 3 & 0 & 0 & 0.5867 & 4 & 0.6333 & 5 \\
\hline Lebanon & 3 & 0 & 0 & 0.1314 & 1 & 0.3722 & 4 \\
\hline Lesotho & 3 & 1 & 1 & 0.255 & 2 & 0.3256 & 3 \\
\hline Libya & 1 & 0 & 0 & 0.792 & 5 & 0.2778 & 3 \\
\hline Lithuania & 3 & 0 & 1 & 0.3223 & 2 & 0.6222 & 5 \\
\hline Luxembourg & 5 & 0 & 1 & 0.5302 & 3 & 0.5494 & 5 \\
\hline Madagascar & 3 & 0 & 0 & 0.8791 & 5 & 0.2222 & 2 \\
\hline Malawi & 3 & 1 & 0 & 0.6744 & 4 & 0.1478 & 2 \\
\hline Malaysia & 4 & 1 & 0 & 0.588 & 4 & 0.0256 & 1 \\
\hline Mali & 3 & 0 & 0 & 0.6906 & 4 & 0.1889 & 2 \\
\hline Malta & 4 & 0 & 1 & 0.0414 & 1 & 0.3944 & 4 \\
\hline Mauritania & 2 & 0 & 0 & 0.615 & 4 & 0.2222 & 2 \\
\hline Mauritius & 4 & 0 & 0 & 0.4634 & 3 & 0.2241 & 3 \\
\hline Mexico & 3 & 0 & 1 & 0.5418 & 4 & 0.2556 & 3 \\
\hline Moldova & 3 & 0 & 0 & 0.5535 & 4 & 0.5222 & 5 \\
\hline Mongolia & 3 & 0 & 0 & 0.3682 & 2 & 0.5111 & 5 \\
\hline Morocco & 3 & 0 & 0 & 0.4841 & 3 & 0.3556 & 4 \\
\hline Mozambique & 2 & 0 & 0 & 0.6932 & 4 & 0.2017 & 2 \\
\hline Myanmar & 2 & 0 & 0 & 0.5062 & 3 & 0.2444 & 3 \\
\hline Namibia & 4 & 1 & 0 & 0.6329 & 4 & 0.2444 & 3 \\
\hline Nepal & 3 & 1 & 0 & 0.6632 & 4 & 0.3111 & 3 \\
\hline Netherlands & 5 & 0 & 1 & 0.1054 & 1 & 0.5811 & 5 \\
\hline New Zealand & 5 & 1 & 0 & 0.3969 & 3 & 0.4556 & 4 \\
\hline Nicaragua & 2 & 0 & 1 & 0.4844 & 3 & 0.1444 & 2 \\
\hline Niger & 2 & 0 & 0 & 0.6518 & 4 & 0.1778 & 2 \\
\hline Nigeria & 2 & 1 & 0 & 0.8505 & 5 & 0.1111 & 1 \\
\hline Norway & 5 & 0 & 0 & 0.0586 & 1 & 0.6889 & 5 \\
\hline Oman & 3 & 0 & 0 & 0.4373 & 3 & 0.2333 & 3 \\
\hline Pakistan & 2 & 1 & 0 & 0.7098 & 5 & 0.3333 & 3 \\
\hline Panama & 3 & 0 & 1 & 0.5528 & 4 & 0.1000 & 1 \\
\hline Papua New Guinea & 3 & 1 & 0 & 0.2718 & 2 & 0.0667 & 1 \\
\hline Paraguay & 2 & 0 & 1 & 0.1689 & 2 & 0.2556 & 3 \\
\hline
\end{tabular}




\begin{tabular}{|c|c|c|c|c|c|c|c|}
\hline Nation & $\begin{array}{l}\text { Property } \\
\text { Rights }\end{array}$ & $\begin{array}{l}\text { Common } \\
\text { Law }\end{array}$ & $\begin{array}{l}\text { Catholic } \\
\text { Religion }\end{array}$ & $\begin{array}{c}\text { Ethnic } \\
\text { Fractionalization }\end{array}$ & $\begin{array}{c}\text { Ethnic } \\
\text { Fractionalization } \\
\text { (quintiles) }\end{array}$ & Latitude & $\begin{array}{c}\text { Latitude } \\
\text { (quintiles) }\end{array}$ \\
\hline Peru & 3 & 0 & 1 & 0.6566 & 4 & 0.1111 & 1 \\
\hline Philippines & 4 & 0 & 1 & 0.2385 & 2 & 0.1444 & 2 \\
\hline Poland & 4 & 0 & 1 & 0.1183 & 1 & 0.5778 & 5 \\
\hline Portugal & 4 & 0 & 1 & 0.0468 & 1 & 0.4367 & 4 \\
\hline Qatar & 3 & 0 & 0 & 0.7456 & 5 & 0.2811 & 3 \\
\hline Romania & 2 & 0 & 0 & 0.3069 & 2 & 0.5111 & 5 \\
\hline Russian Federation & 3 & 0 & 0 & 0.2452 & 2 & 0.6667 & 5 \\
\hline Rwanda & 1 & 0 & 1 & 0.3238 & 2 & 0.0222 & 1 \\
\hline Samoa & 3 & 1 & 0 & 0.1376 & 1 & 0.1483 & 2 \\
\hline Saudi Arabia & 3 & 1 & 0 & 0.18 & 2 & 0.2778 & 3 \\
\hline Senegal & 3 & 0 & 0 & 0.6939 & 4 & 0.1556 & 2 \\
\hline Sierra Leone & 2 & 1 & 0 & 0.8191 & 5 & 0.0922 & 1 \\
\hline Singapore & 5 & 1 & 0 & 0.3857 & 3 & 0.0136 & 1 \\
\hline Slovak Republic & 3 & 0 & 1 & 0.2539 & 2 & 0.5378 & 5 \\
\hline Slovenia & 4 & 0 & 1 & 0.2216 & 2 & 0.5111 & 5 \\
\hline Somalia & 1 & 1 & 0 & 0.8117 & 5 & 0.1111 & 1 \\
\hline South Africa & 3 & 1 & 0 & 0.7517 & 5 & 0.3222 & 3 \\
\hline Spain & 4 & 0 & 1 & 0.4165 & 3 & 0.4444 & 4 \\
\hline Sri Lanka & 3 & 1 & 0 & 0.415 & 3 & 0.0778 & 1 \\
\hline Sudan & 2 & 1 & 0 & 0.7147 & 5 & 0.1667 & 2 \\
\hline Suriname & 3 & 0 & 0 & 0.7332 & 5 & 0.0444 & 1 \\
\hline Swaziland & 4 & 1 & 0 & 0.0582 & 1 & 0.2922 & 3 \\
\hline Sweden & 4 & 0 & 0 & 0.06 & 1 & 0.6889 & 5 \\
\hline Switzerland & 5 & 0 & 1 & 0.5314 & 3 & 0.5222 & 5 \\
\hline Syrian Arab Republic & 2 & 0 & 0 & 0.5399 & 3 & 0.3889 & 4 \\
\hline Taiwan, China & 5 & 0 & 0 & 0.2744 & 2 & 0.2589 & 3 \\
\hline Tajikistan & 2 & 0 & 0 & 0.5107 & 3 & 0.4333 & 4 \\
\hline Tanzania & 3 & 1 & 0 & 0.7353 & 5 & 0.0667 & 1 \\
\hline Thailand & 4 & 1 & 0 & 0.6338 & 4 & 0.1667 & 2 \\
\hline Togo & 2 & 0 & 0 & 0.7099 & 5 & 0.0889 & 1 \\
\hline Trinidad and Tobago & 5 & 1 & 1 & 0.6475 & 4 & 0.1222 & 1 \\
\hline Tunisia & 3 & 0 & 0 & 0.0394 & 1 & 0.3778 & 4 \\
\hline Turkey & 4 & 0 & 0 & 0.32 & 2 & 0.4333 & 4 \\
\hline Turkmenistan & 2 & 0 & 0 & 0.3918 & 3 & 0.4444 & 4 \\
\hline Uganda & 3 & 1 & 1 & 0.9302 & 5 & 0.0111 & 1 \\
\hline Ukraine & 2 & 0 & 0 & 0.4737 & 3 & 0.5444 & 5 \\
\hline United Arab Emirates & 5 & 1 & 0 & 0.6252 & 4 & 0.2667 & 3 \\
\hline United Kingdom & 5 & 1 & 0 & 0.1211 & 1 & 0.6000 & 5 \\
\hline United States & 5 & 1 & 0 & 0.4901 & 3 & 0.4222 & 4 \\
\hline Uruguay & 4 & 0 & 1 & 0.2504 & 2 & 0.3667 & 4 \\
\hline Uzbekistan & 2 & 0 & 0 & 0.4125 & 3 & 0.4556 & 4 \\
\hline Venezuela, RB & 3 & 0 & 1 & 0.4966 & 3 & 0.0889 & 1 \\
\hline Vietnam & 1 & 0 & 0 & 0.2383 & 2 & 0.1778 & 2 \\
\hline Zambia & 3 & 1 & 0 & 0.7808 & 5 & 0.1667 & 2 \\
\hline Zimbabwe & 2 & 1 & 0 & 0.3874 & 3 & 0.2222 & 2 \\
\hline
\end{tabular}




\section{Table 2: Summary Statistics}

Panel A presents the summary statistics and Panel B presents the correlation matrix between the variables. P-values are listed in parentheses in panel B. The variables are defined as follows: Property Rights, scored from 1 to 5, reflects the degree to which government enforces laws that protect private property, with higher numbers indicating better enforcement. Common Law takes the value 1 for Common Law countries and 0 for other countries. Catholic Religion takes the value 1 if Catholics are the dominant religious group in the country and 0 if it is some other religious group. Ethnic Fractionalization is the probability that two randomly selected individuals in a country will not speak the same language. Latitude is the absolute value of the latitude of the country scaled between zero and one. Latitude and Ethnic Fractionalization are re-scaled into quintiles. Property Rights are from the Heritage Foundation for the year 2000.

\section{Panel A:}

\begin{tabular}{lccccc}
\hline Variable & N & Mean & $\begin{array}{c}\text { Standard } \\
\text { Deviation }\end{array}$ & Minimum & Maximum \\
\hline $\begin{array}{l}\text { Property Rights } \\
\text { Common Law }\end{array}$ & 158 & 3.13 & 1.19 & 1 & 5 \\
$\begin{array}{l}\text { Catholic } \\
\text { Religion }\end{array}$ & 158 & 0.3 & 0.46 & 0 & 1 \\
$\begin{array}{l}\text { Ethnic } \\
\text { Fractionalization }\end{array}$ & 158 & 0.32 & 0.47 & 0 & 1 \\
Latitude & 158 & 2.99 & 1.42 & 1 & 5 \\
& 158 & 2.96 & 1.43 & 1 & 5 \\
\hline
\end{tabular}

Panel B:

\begin{tabular}{|c|c|c|c|c|}
\hline & $\begin{array}{l}\text { Property } \\
\text { Rights }\end{array}$ & $\begin{array}{l}\text { Common } \\
\text { Law }\end{array}$ & $\begin{array}{l}\text { Catholic } \\
\text { Religion }\end{array}$ & $\begin{array}{l}\text { Ethnic } \\
\text { Fractionalization }\end{array}$ \\
\hline Common Law & $0.1813^{b}$ & & & \\
\hline Catholic Religion & 0.0938 & $-0.2794^{\mathrm{a}}$ & & \\
\hline Ethnic & & & & \\
\hline Fractionalization & $-0.3462^{a}$ & $0.1616^{b}$ & -0.0895 & \\
\hline Latitude & $0.3358^{\mathrm{a}}$ & $-0.2621^{\mathrm{a}}$ & -0.067 & $-0.5459^{a}$ \\
\hline
\end{tabular}




\section{Table 3: Independence Relations found by Tetrad}

The variables are defined as follows: Property Rights, scored from 1 to 5, reflects the degree to which government enforces laws that protect private property, with higher numbers indicating better enforcement. Common Law takes the value 1 for Common Law countries and 0 for other countries. Catholic Religion takes the value 1 if Catholics are the dominant religious group in the country and 0 if it is some other religious group. Ethnic Fractionalization is the probability that two randomly selected individuals in a country do not belong to the same ethnic group. Latitude is the absolute value of the latitude of the country scaled between zero and one. Latitude and Ethnic Fractionalization are re-scaled into quintiles. Property Rights are from the Heritage Foundation for the year 2000. The table shows the sample correlations and p-values that correspond to the probability that the absolute value of the sample (partial) correlation exceeds the observed value, on the assumption of zero (partial) correlation in the population, assuming a multi-normal distribution.

\section{Panel A: 5\% Significance Level}

\begin{tabular}{llcll}
\hline & (Partial) Correlation & $\begin{array}{c}\text { Sample } \\
\text { Correlation }\end{array}$ & p-values & Edge Removed \\
\hline \multicolumn{2}{l}{ Independence Relations } & & & \\
I $\quad$ Rho (Property Rights, Catholic) & 0.0938 & 0.2418 & Property Rights-Catholic Religion \\
II $\quad$ Rho (Catholic, Ethnic Fractionalization) & -0.0895 & 0.2639 & Catholic---Ethnic Fractionalization \\
III $\quad$ Rho (Catholic, Latitude) & -0.0670 & 0.4042 & Catholic---Latitude \\
Conditional Independence Relations & & 0.0229 & 0.7761 & Common--- Ethnic Fractionalization \\
IV Rho (Common, Ethnic Fractionalization | Latitude) & R & & \\
\hline
\end{tabular}


Table 4: Determinants of Property Rights Protection-OLS Regressions

The regression equation estimated is Outcome Variable $=a+b_{1}$ Common Law $+b_{2}$ Catholic Religion $+b_{3}$ Ethnic Fractionalization $+b_{4}$ Latitude $+e$. In Panel A, specifications (1)-(4), the outcome variable is Property Rights, in specifications (5)-(7), the outcome variable is Common Law, in specifications (8)-(10), the outcome variable is Catholic Religion, in specifications (11)-(13), the outcome variable is Ethnic Fractionalization, in specifications (14)-(16), the outcome variable is Latitude. The variables are defined as follows: Property Rights, scored from 1 to 5 , reflects the degree to which government enforces laws that protect private property, with higher numbers indicating better enforcement. Common Law takes the value 1 for Common Law countries and 0 for other countries.

Catholic Religion takes the value 1 if Catholics are the dominant religious group in the country and 0 if it is some other religious group. Ethnic Fractionalization is the probability that two randomly

selected individuals in a country do not belong to the same ethnic group. Latitude is the absolute value of the latitude of the country scaled between zero and one. Property Rights are from the Heritage Foundation for the year 2000. Latitude and Ethnic Fractionalization are re-scaled into quintiles. The table shows the sample correlations and the p-values that correspond to the probability that the absolute value of the sample(partial) correlation exceeds the observed value, on the assumption of zero (partial) correlation in the population, assuming a multinormal distribution.

\section{Panel A: Independence Relations Implied by OLS}

\begin{tabular}{|c|c|c|c|c|c|c|c|c|c|c|c|c|c|c|c|c|}
\hline & 1 & 2 & 3 & 4 & 5 & 6 & 7 & 8 & 9 & 10 & 11 & 12 & 13 & 14 & 15 & 16 \\
\hline & $\begin{array}{c}\text { Property } \\
\text { Rights }\end{array}$ & $\begin{array}{c}\text { Property } \\
\text { Rights }\end{array}$ & $\begin{array}{c}\text { Property } \\
\text { Rights }\end{array}$ & $\begin{array}{c}\text { Property } \\
\text { Rights }\end{array}$ & Latitude & Latitude & Latitude & Ethnic & Ethnic & Ethnic & $\begin{array}{c}\text { Common } \\
\text { Law }\end{array}$ & $\begin{array}{c}\text { Common } \\
\text { Law }\end{array}$ & $\begin{array}{c}\text { Common } \\
\text { Law }\end{array}$ & $\begin{array}{l}\text { Catholic } \\
\text { Religion } \\
\end{array}$ & $\begin{array}{l}\text { Catholic } \\
\text { Religion } \\
\end{array}$ & $\begin{array}{l}\text { Catholic } \\
\text { Religion }\end{array}$ \\
\hline Latitude & $\begin{array}{c}0.279^{\mathrm{a}} \\
(0.063)\end{array}$ & & & & & & & $\begin{array}{l}-0.541^{\mathrm{a}} \\
(0.066)\end{array}$ & & & $\begin{array}{l}-0.084^{\mathrm{a}} \\
(0.025)\end{array}$ & & & $\begin{array}{c}-0.022 \\
(0.026)\end{array}$ & & \\
\hline Ethnic & & $\begin{array}{l}-0.290^{\mathrm{a}} \\
(0.063)\end{array}$ & & & $\begin{array}{l}-0.551^{\mathrm{a}} \\
(0.068)\end{array}$ & & & & & & & $\begin{array}{c}0.053^{\mathrm{b}} \\
(0.026)\end{array}$ & & & $\begin{array}{c}-0.03 \\
(0.026)\end{array}$ & \\
\hline $\begin{array}{l}\text { Common } \\
\text { Law }\end{array}$ & & & $\begin{array}{c}0.467^{b} \\
(0.203)\end{array}$ & & & $\begin{array}{l}-0.813^{\mathrm{a}} \\
(0.240)\end{array}$ & & & $\begin{array}{l}0.497^{\mathrm{b}} \\
(0.243)\end{array}$ & & & & & & & $\begin{array}{l}-0.284^{\mathrm{a}} \\
(0.078)\end{array}$ \\
\hline $\begin{array}{l}\text { Catholic } \\
\text { Religion }\end{array}$ & & & & $\begin{array}{c}0.238 \\
(0.202)\end{array}$ & & & $\begin{array}{l}-0.205 \\
(0.244)\end{array}$ & & & $\begin{array}{c}-0.271 \\
(0.241)\end{array}$ & & & $\begin{array}{l}-0.275^{\mathrm{a}} \\
(0.076)\end{array}$ & & & \\
\hline $\mathrm{N}$ & 158 & 158 & 158 & 158 & 158 & 158 & 158 & 158 & 158 & 158 & 158 & 158 & 158 & 158 & 158 & 158 \\
\hline R-squared & 0.113 & 0.12 & 0.033 & 0.009 & 0.298 & 0.069 & 0.004 & 0.298 & 0.026 & 0.008 & 0.069 & 0.026 & 0.078 & 0.004 & 0.008 & 0.078 \\
\hline
\end{tabular}

and ${ }^{\mathrm{b}}$ represent significance at 1 and $5 \%$ respectively. 
Panel B: Conditional Independence Relations Implied by OLS

\begin{tabular}{|c|c|c|c|c|c|c|c|c|c|c|}
\hline & 1 & 2 & 3 & 4 & 5 & 6 & 7 & 8 & 9 & 10 \\
\hline & \multicolumn{4}{|c|}{ Independence Relations } & \multicolumn{6}{|c|}{ Conditional Independence Relations } \\
\hline & $\begin{array}{c}\text { Property } \\
\text { Rights }\end{array}$ & $\begin{array}{c}\text { Property } \\
\text { Rights }\end{array}$ & $\begin{array}{c}\text { Property } \\
\text { Rights }\end{array}$ & $\begin{array}{c}\text { Property } \\
\text { Rights }\end{array}$ & $\begin{array}{c}\text { Property } \\
\text { Rights }\end{array}$ & $\begin{array}{c}\text { Property } \\
\text { Rights }\end{array}$ & $\begin{array}{c}\text { Property } \\
\text { Rights }\end{array}$ & $\begin{array}{c}\text { Property } \\
\text { Rights }\end{array}$ & $\begin{array}{c}\text { Property } \\
\text { Rights }\end{array}$ & $\begin{array}{c}\text { Property } \\
\text { Rights }\end{array}$ \\
\hline Latitude & $\begin{array}{c}0.279^{\mathrm{a}} \\
(0.063)\end{array}$ & & & & $\begin{array}{c}0.174^{\mathrm{b}} \\
{[0.073]}\end{array}$ & $\begin{array}{c}0.342^{\mathrm{a}} \\
{[0.062]}\end{array}$ & $\begin{array}{c}0.286^{\mathrm{a}} \\
{[0.063]}\end{array}$ & & & \\
\hline Ethnic & & $\begin{array}{l}-0.290^{\mathrm{a}} \\
(0.063)\end{array}$ & & & $\begin{array}{l}-0.195^{\mathrm{a}} \\
{[0.074]}\end{array}$ & & & $\begin{array}{l}-0.323^{\mathrm{a}} \\
{[0.062]}\end{array}$ & $\begin{array}{l}-0.286^{\mathrm{a}} \\
{[0.063]}\end{array}$ & \\
\hline $\begin{array}{l}\text { Common } \\
\text { Law }\end{array}$ & & & $\begin{array}{c}0.467^{\mathrm{b}} \\
(0.203)\end{array}$ & & & $\begin{array}{c}0.746^{\mathrm{a}} \\
{[0.193]}\end{array}$ & & $\begin{array}{c}0.628^{\mathrm{a}} \\
{[0.190]}\end{array}$ & & $\begin{array}{c}0.580^{\mathrm{a}} \\
{[0.210]}\end{array}$ \\
\hline $\begin{array}{l}\text { Catholic } \\
\text { Religion }\end{array}$ & & & & $\begin{array}{c}0.238 \\
(0.202)\end{array}$ & & & $\begin{array}{c}0.296 \\
{[0.191]}\end{array}$ & & $\begin{array}{c}0.161 \\
{[0.191]}\end{array}$ & $\begin{array}{c}0.398 \\
{[0.206]}\end{array}$ \\
\hline $\begin{array}{l}\mathrm{N} \\
\mathrm{R}- \\
\text { squared }\end{array}$ & $\begin{array}{c}158 \\
0.113\end{array}$ & 158 & 158 & 158 & 158 & $\begin{array}{c}158 \\
0.191\end{array}$ & 158 & $\begin{array}{c}158 \\
0.178\end{array}$ & 158 & 158 \\
\hline
\end{tabular}

$\begin{array}{ccccc}\text { squared } & 0.113 & 0.12 & 0.033 & 0.009 \\ { }^{\mathrm{a}} \text { and }{ }^{\mathrm{b}} \text { represent significance at } 1,5 \text { and } & 10 \% \text { respectively. }\end{array}$ 


\section{Table 5: Determinants of Property Rights Protection-Robustness using TETRAD}

Panel A presents the pattern between the variables when we alter the significance level. Panel B presents the pattern for different samples of countries. Panel C uses Good Crops as an alternative indicator to Latitude. Panel D uses two alternate measures of property rights protection: Constraints on the Executive from Polity IV and Risk of Expropriation from PRS. The variables are defined as follows: Property Rights, scored from 1 to 5, reflects the degree to which government enforces laws that protect private property, with higher numbers indicating better enforcement. Property Rights are from the Heritage Foundation for the year 2000. Common Law takes the value 1 for Common Law countries and 0 for other countries. Catholic Religion takes the value 1 if Catholics are the dominant religious group in the country and 0 if it is some other religious group. Ethnic Fractionalization is the probability that two randomly selected individuals in a country do not belong to the same ethnic group. Latitude is the absolute value of the latitude of the country scaled between zero and one. Good Crops equals (1+zmaize+zwheat)/(1+zrice+zsugarcane), where $\mathrm{zX}$ equals the share of the land area that is judged to be suitable by FAO for growing crop X. Data are from Easterly and Levine (2003). Settler Mortality is the log of the annualized deaths per thousand European soldiers in European colonies in the early $19^{\text {th }}$ century. Risk of Expropriation is an index compiled by Political Risk Services and is the risk of expropriation of private foreign investment by government. It is scaled from 0 to 10, where a higher score means less risk. We use data for the year 1995. Legal Formalism is a measure of procedural formalism in connection with collecting a bounced check. Number of Procedures is a measure of contract enforcement and is the number of procedures necessary to resolve a court case involving this same commercial debt. Procedural Complexity measures the difficulties in resolving the case of an unpaid commercial debt. Latitude, Ethnic Fractionalization, Settler Mortality and Good Crops are re-scaled into quantiles. Detailed Variable Definitions are in the appendix.

Panel A : Dropping Different Samples of Countries

\begin{tabular}{|c|c|c|c|c|}
\hline Full Sample & Drop Transition & Drop Africa & Drop Latin America & Drop Settler Countries \\
\hline$N=158$ & $N=126$ & $\mathrm{~N}=112$ & $N=138$ & $N=154$ \\
\hline Ethnic $\rightarrow$ Property Rights & Ethnic $\rightarrow$ Property Rights & Ethnic $\rightarrow$ Property Rights & Ethnic $\rightarrow$ Property Rights & Ethnic $\rightarrow$ Property Rights \\
\hline Latitude $\rightarrow$ Property Rights & Latitude $\rightarrow$ Property Rights & Common $\rightarrow$ Property Rights & Latitude $\rightarrow$ Property Rights & Latitude --- Common Law \\
\hline Common $\rightarrow$ Property Rights & Common $<>$ Catholic & Latitude --- Common Law & Common $\rightarrow$ Property Rights & Catholic $\rightarrow$ Common Law \\
\hline Latitude $\rightarrow$ Common Law & Latitude $<>$ Ethnic & Catholic $\rightarrow$ Common Law & Latitude --- Common Law & Ethnic $\rightarrow$ Latitude \\
\hline $\begin{array}{l}\text { Catholic } \rightarrow \text { Common Law } \\
\text { Latitude }<>\text { Ethnic }\end{array}$ & & Ethnic $\rightarrow$ Latitude & $\begin{array}{l}\text { Catholic } \rightarrow \text { Common Law } \\
\text { Ethnic } \rightarrow \text { Latitude }\end{array}$ & \\
\hline \multicolumn{5}{|c|}{ Panel B : Use Alternative Endowments Variable-Good Crops } \\
\hline Full Sample & Drop Transition & Drop Africa & Drop Latin America & Drop Settler Countries \\
\hline $\mathrm{N}=145$ & $\mathrm{~N}=\mathbf{1 1 3}$ & $\mathrm{N}=\mathbf{1 0 1}$ & $\mathrm{N}=\mathbf{1 2 6}$ & $\mathrm{N}=141$ \\
\hline Ethnic $\rightarrow$ Property Rights & Ethnic $\rightarrow$ Property Rights & Ethnic $\rightarrow$ Property Rights & Ethnic $\rightarrow$ Property Rights & Ethnic $\rightarrow$ Property Rights \\
\hline Good Crops $\rightarrow$ Property Rights & Good Crops $\rightarrow$ Property Rights & Common Law $\rightarrow$ Property Rights & Good Crops $\rightarrow$ Property Rights & Good Crops $\rightarrow$ Property Rights \\
\hline Catholic $\rightarrow$ Common Law & Common Law $\rightarrow$ Catholic & Common Law $<>$ Catholic & Catholic $\rightarrow$ Common Law & Catholic $\rightarrow$ Common Law \\
\hline Ethnic --- Common Law & Catholic --- Good Crops & Ethnic $<>$ Good Crops & Ethnic --- Common Law & Ethnic --- Common Law \\
\hline Good Crops $\rightarrow$ Ethnic & Ethnic $\rightarrow$ Good Crops & & Good Crops $\rightarrow$ Ethnic & Good Crops $\rightarrow$ Ethnic \\
\hline \multicolumn{5}{|c|}{ Panel C : Use Alternative Endowments Variable-Settler Mortality } \\
\hline Full Sample & Drop Transition & Drop Africa & Drop Latin America & Drop Settler Countries \\
\hline $\mathrm{N}=63$ & $\mathrm{~N}=62$ & $\mathbf{N}=\mathbf{3 7}$ & $\mathrm{N}=45$ & $\mathrm{~N}=59$ \\
\hline Settler Mortality $\rightarrow$ Property Rights & Settler Mortality $\rightarrow$ Property & Settler Mortality $\rightarrow$ Property Rights & Settler Mortality $\rightarrow$ Property Rights & Settler Mortality $\rightarrow$ Property Rights \\
\hline Ethnic $\rightarrow$ Settler Mortality & Ethnic $\rightarrow$ Settler Mortality & Common $\rightarrow$ Property Rights & Common $\rightarrow$ Property Rights & Common $<>$ Catholic \\
\hline Common --- Settler Mortality & Common --- Settler Mortality & Settler Mortality $\rightarrow$ Common & Common $\rightarrow$ Settler Mortality & Ethnic $\rightarrow$ Settler Mortality \\
\hline Catholic $\rightarrow$ Common Law & Catholic $\rightarrow$ Common Law & Catholic $\rightarrow$ Common Law & Ethnic $\rightarrow$ Settler Mortality & \\
\hline
\end{tabular}


Panel D : Use Alternative Measure of Property Rights Protection-Risk of Expropriation

\begin{tabular}{llll}
\hline Full Sample & Drop Transition & Drop Africa & Drop Latin America \\
\hline $\mathbf{N}=\mathbf{1 1 5}$ & $\mathbf{N}=\mathbf{1 0 5}$ & $\mathbf{N = 7 8}$ & $\mathbf{N}=\mathbf{9 6}$ \\
\hline Ethnic $\rightarrow$ Risk of Expropriation & Ethnic $\rightarrow$ Risk of Expropriation & Latitude $\rightarrow$ Risk of Expropriation & Ethnic $\rightarrow$ Risk of Expropriation \\
Catholic $\rightarrow$ Common Law & Catholic $<>$ Common Law & Catholic $<>$ Common Law & Latitude $\rightarrow$ Risk of Expropriation $\quad$ Catholic $\rightarrow$ Common Law \\
Latitude $\rightarrow$ Common Law & Ethnic $<>$ Latitude & Ethnic $<>$ Latitude & Catholic $\rightarrow$ Common Law \\
Ethnic $<>$ Latitude & & & Latitude $\rightarrow$ Common Law \\
& & & Ethnic $<>$ Latitude \\
\end{tabular}

\begin{tabular}{lll}
\hline \multicolumn{2}{l}{ Panel $\mathbf{E}:$ Use Alternative Dependent } & Variables \\
\hline Legal Formalism & Procedural Complexity & Number of Procedures \\
\hline $\mathbf{N}=\mathbf{1 0 2}$ & $\mathbf{N}=\mathbf{1 0 7}$ & $\mathbf{N}=\mathbf{1 0 7}$ \\
& Common Law $\rightarrow$ Procedural & \\
Common Law $\rightarrow$ Formalism & Complexity & Ethnic $\rightarrow$ No. of Procedures \\
Catholic $\rightarrow$ Common Law & Catholic $\rightarrow$ Procedural Complexity & Common Law $\rightarrow$ No. of Procedures \\
Common Law --- Latitude & Catholic $<>$ Common & Catholic $<>$ Common \\
Ethnic $\rightarrow$ Latitude & Ethnic $<>$ Latitude & Ethnic $<>$ Latitude \\
& &
\end{tabular}

\begin{tabular}{lc}
\hline Panel F: 100 Random Sorts & \\
\hline Only Ethnic & 34 \\
Only Latitude & 14 \\
Ethnic and Latitude & 12 \\
Ethnic and Common & 11 \\
Latitude and Common & 25 \\
Ethnic, Latitude and Common & 2 \\
Latitude and Catholic & 1 \\
Latitude, Common and Catholic & 1 \\
& 100 \\
\hline
\end{tabular}




\section{Table 6: Testing the Robustness of Ethnic using Extreme Bounds Analysis (EBA)}

Panel A presents the results from extreme bounds analysis (EBA). Panel B presents robustness results using the Sala-i-Martin (1997) method. The regression equation estimated is Property Rights $=$ a + $b_{1}$ Legal Origin $+b_{2}$ Religion $+b_{3}$ Ethnic Fractionalization $+b_{4}$ Latitude + e. Panel A presents the lower and extreme bound values and the corresponding $t$-stats and p-values. The conditioning information set associated with the two extreme bounds are also reported. In Panel A, the variable Latitude is said to be robust if the two extreme bounds are statistically significant and of the same sign. Panel B presents the weighted mean and weighted standard deviation for Latitude across all possible conditioning information sets. The weights are proportional to the likelihoods of each model and are described in Sala-i-Martin (1997). Panel B also reports the cumulative normal distribution function at zero (CDF(0)) using the weighted mean and weighted standard deviation as parameters. A variable is said to be robust if $\operatorname{CDF}(0)>0.95$. The variables are defined as follows: Property Rights, scored from 1 to 5 , reflects the degree to which government enforces laws that protect private property, with higher numbers indicating better enforcement. Property Rights are from the Heritage Foundation for the year 2000. Legal Origin takes the value 1 for Common Law countries, 2 for French civil law countries, 3 for German Civil law countries and Scandinavian civil law countries and 4 for Socialist Law countries. Religion takes the value 1 if Catholics are the dominant religious group in the country, 2 if Muslims are the dominant religious group, 3 if Protestants are the dominant religious group and 4 if it is some other religious group. Ethnic Fractionalization is the probability that two randomly selected individuals in a country do not belong to the same ethnic group. Latitude is the absolute value of the latitude of the country scaled between zero and one. Latitude and Ethnic Fractionalization are re-scaled into quantiles. Detailed Variable Definitions are in the appendix.

Panel A1: Extreme Bounds Analysis at 5\% Level Significance

\begin{tabular}{|c|c|c|c|c|c|}
\hline & Conditioning Information Set & Extreme Bound value & t-stat & p-value & Robust/Not Robust \\
\hline \multicolumn{6}{|c|}{ ETHNIC FRACTIONALIZATION } \\
\hline Lower Extreme Bound & Common Law & -0.447 & -5.22 & 0.000 & \\
\hline \multicolumn{6}{|l|}{ LATITUDE } \\
\hline Upper Extreme Bound & Common Law, Catholic & 0.492 & 6.03 & 0.000 & Robust \\
\hline Lower Extreme Bound & Ethnic Fractionalization & 0.028 & 2.37 & 0.019 & \\
\hline Upper Extreme Bound & Latitude, Catholic & 1.326 & 4.70 & 0.000 & Robust \\
\hline Lower Extreme Bound & Catholic & 0.160 & 2.77 & 0.006 & \\
\hline \multicolumn{6}{|c|}{ Panel A2: Extreme Bounds Analysis at 1\% Level Significance } \\
\hline & Conditioning Information Set & Extreme Bound value & t-stat & p-value & Robust/Not Robust \\
\hline \multicolumn{6}{|l|}{ LATITUDE } \\
\hline Upper Extreme Bound & Common Law, Catholic & 0.553 & 6.03 & 0.000 & Not Robust \\
\hline Lower Extreme Bound & Ethnic Fractionalization & -0.045 & 2.37 & 0.019 & \\
\hline
\end{tabular}


Panel B: Sala-i-Martin Specification

\begin{tabular}{lccccc} 
& & & Robustness at 5\% Level & Robustness at 1\% Level \\
\hline Variable & $\begin{array}{l}\text { Weighted } \\
\text { Mean }\end{array}$ & $\begin{array}{l}\text { Weighted Standard } \\
\text { Deviation }\end{array}$ & $\begin{array}{l}\text { Cumulative Distribution } \\
\text { Function (0) }\end{array}$ & Robust (>0.95) / Not Robust & Robust (>0.99) / Not Robust \\
\hline Ethnic Fractionalization & -0.240 & 0.068 & 0.999 & Robust & Robust \\
Latitude & 0.265 & 0.068 & 0.999 & Robust & Robust \\
Common Law & 0.754 & 0.196 & 0.999 & Robust & Robust \\
\hline
\end{tabular}




\section{Table 7: Determining Error Probabilities using Monte Carlo Analysis}

Panel A presents the results from Monte Carlo Simulations performed at differing significance levels. The null hypothesis tested is Only Ethnic $\rightarrow$ Property Rights. The 2-Tier Temporal Order corresponds to Figure 3 where Tier 1 consists of Latitude, Common Law, Catholic Religion and Ethnic Fractionalization and Tier 2 consists of Property Rights. The number in each cell in panel A represents the frequency (out of a 100 datasets) with which the null hypothesis is rejected. In Panel B, the alternate model is Ethnic $\rightarrow$ Property Rights and Latitude $\rightarrow$ Property Rights and Common Law $\rightarrow$ Property Rights. The number in each cell represents the frequency (out of a 100 datasets) with which the null hypothesis (Only Ethnic $\rightarrow$ Property Rights and Latitude and Common Law do not affect Property Rights) is accepted.

\section{Panel A: Percentage of Type I errors}

\begin{tabular}{|c|c|c|c|c|c|}
\hline Sample Size & 50 & 100 & 150 & 200 & 250 \\
\hline \multicolumn{6}{|l|}{ Null Hypothesis: Ethnic --> Property Rights } \\
\hline \multicolumn{6}{|l|}{ Significance $=5 \%$} \\
\hline Percentage of cases when the null was rejected $(\alpha)$ & 44 & 21 & 4 & 11 & 4 \\
\hline \multicolumn{6}{|l|}{ Significance $=1 \%$} \\
\hline Percentage of cases when the null was rejected $(\alpha)$ & & & & & \\
\hline
\end{tabular}

\section{Panel B: Percentage of Type II Errors from Alternate Model}

\section{Sample Size}

100

150

200

Alternate Model: Ethnic $\rightarrow$ Property Rights and Latitude $\rightarrow$ Property Rights and Common --> Property Rights

Significance $=5 \%$

Percentage of cases when null is accepted $(\beta)$

Significance $=1 \%$

Percentage of cases when null is accepted ( $\beta$ )

0

0

0

\begin{tabular}{lll}
0 & 0 & 0 \\
0 & 0 & 0 \\
\hline
\end{tabular}




\section{Appendix A1: Variable Definitions}

\begin{tabular}{|c|c|c|}
\hline Variable & Definition & Source \\
\hline \multicolumn{3}{|l|}{ Dependent Variables } \\
\hline Property Rights & $\begin{array}{l}\text { Scored from } 1 \text { to } 5 \text {, property rights reflects the degree to which } \\
\text { government enforces laws that protect private property, with higher } \\
\text { numbers indicating better enforcement. Year } 2000 \text { values are used. }\end{array}$ & Heritage Foundation \\
\hline & $\begin{array}{l}\text { A seven category scale, from } 1 \text { to } 7 \text {, with a higher score indicating more } \\
\text { constraint. Score of } 1 \text { indicates unlimited authority; score of } 3 \text { indicates } \\
\text { slight to moderate limitations; score of } 5 \text { indicates substantial } \\
\text { limitations; score of } 7 \text { indicates executive parity or subordination. Scores }\end{array}$ & \\
\hline Constraint on the Executive & of 2, 4, and 6 indicate intermediate values. Year 2000 values were used. & $\begin{array}{l}\text { Polity IV Dataset } \\
\text { The original compilers of the data are Political Risk }\end{array}$ \\
\hline $\begin{array}{l}\text { Risk of Expropriation } \\
\text { Legal Formalism }\end{array}$ & $\begin{array}{l}\text { Risk of expropriation of private foreign investment by government, from } \\
0 \text { to } 10 \text {, where a higher score means less risk. We use the } 1995 \text { values. } \\
\text { Scored } 1 \text { to } 7 \text {, it is an index for formality in legal procedures for } \\
\text { collecting a bounced check }\end{array}$ & $\begin{array}{l}\text { Services. They are organized in electronic form by the } \\
\text { IRIS Center. } \\
\text { Djankov, La Porta, Lopez-de-Silanes and Shleifer } \\
\text { (2003) }\end{array}$ \\
\hline Number of Procedures & $\begin{array}{l}\text { Number of procedures involved in collecting a commercial debt valued } \\
\text { at } 50 \% \text { of annual GDP per capita } \\
\text { Index of complexity involved in collecting a commercial debt valued at }\end{array}$ & World Bank Doing Business Database \\
\hline Procedural Complexity & $50 \%$ of annual GDP per capita & \\
\hline \multicolumn{3}{|l|}{ Independent Variables } \\
\hline Legal Origin & $\begin{array}{l}\text { An indicator of the type of legal system in the country. It takes the value } \\
1 \text { for English Common law, } 2 \text { for French Civil Law, } 3 \text { for German Civil } \\
\text { Law, } 4 \text { for Scandinavian Civil Law and } 5 \text { for Socialist Law countries }\end{array}$ & $\begin{array}{l}\text { La Porta, Lopez-de-Silanes, Shleifer and Vishny } \\
\text { (1999) }\end{array}$ \\
\hline Common & $\begin{array}{l}\text { Common Law dummy that takes the value } 1 \text { for English Common Law } \\
\text { countries and } 0 \text { otherwise }\end{array}$ & $\begin{array}{l}\text { La Porta, Lopez-de-Silanes, Shleifer and Vishny } \\
\text { (1999) }\end{array}$ \\
\hline Religion & $\begin{array}{l}\text { An indicator of the dominant religious group in the country. It takes the } \\
\text { value } 1 \text { for Catholics, } 2 \text { for Protestants, } 3 \text { for Muslims, and } 4 \text { for Others }\end{array}$ & $\begin{array}{l}\text { La Porta, Lopez-de-Silanes, Shleifer and Vishny } \\
\text { (1999) }\end{array}$ \\
\hline Ethnic Fractionalization & $\begin{array}{l}\text { Probability that two randomly selected individuals in a country do not } \\
\text { belong to the same ethnic group }\end{array}$ & Alesina, et al (2003) \\
\hline Latitude & Absolute value of the latitude of a country, scaled between zero and one & $\begin{array}{l}\text { La Porta, Lopez-de-Silanes, Shleifer and Vishny } \\
\text { (1999) }\end{array}$ \\
\hline Good Crops & $\begin{array}{l}\text { Good Crops equals }(1+\text { zmaize+zwheat }) /(1+\text { zrice+zsugarcane }) \text {, where } \mathrm{zX} \\
\text { equals the share of the land area that is judged to be suitable by FAO for } \\
\text { growing crop X. }\end{array}$ & Easterly and Levine (2003) \\
\hline
\end{tabular}




\section{Appendix A2: From Conditional Independence Relations to Directed Acyclic Graphs.}

The following steps are for the case of a two tier temporal order assuming a 5\% significance level for the correlations:

Step 1: Start with a complete undirected graph showing all adjacencies

\section{Figure (a):}

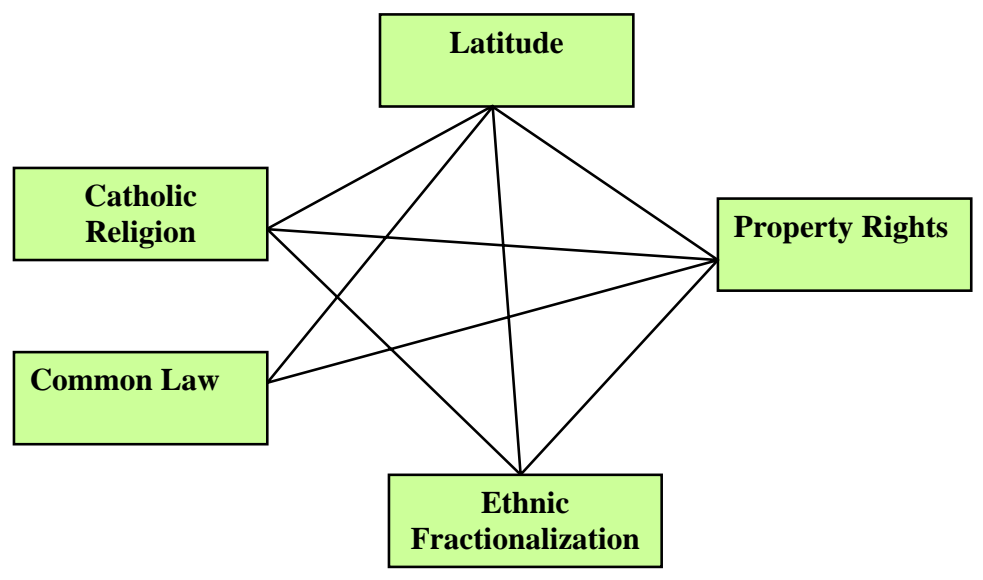

Step 2: Identify the edges with zero unconditional correlations: The independence relations found in the data by TETRAD (Table 3) are as follows:

Property Rights is independent of Catholic Religion

Catholic Religion is independent of Ethnic Fractionalization

Catholic Religion is independent of Latitude

Removing the edges with zero unconditional correlations we obtain the following figure:

Figure (b):

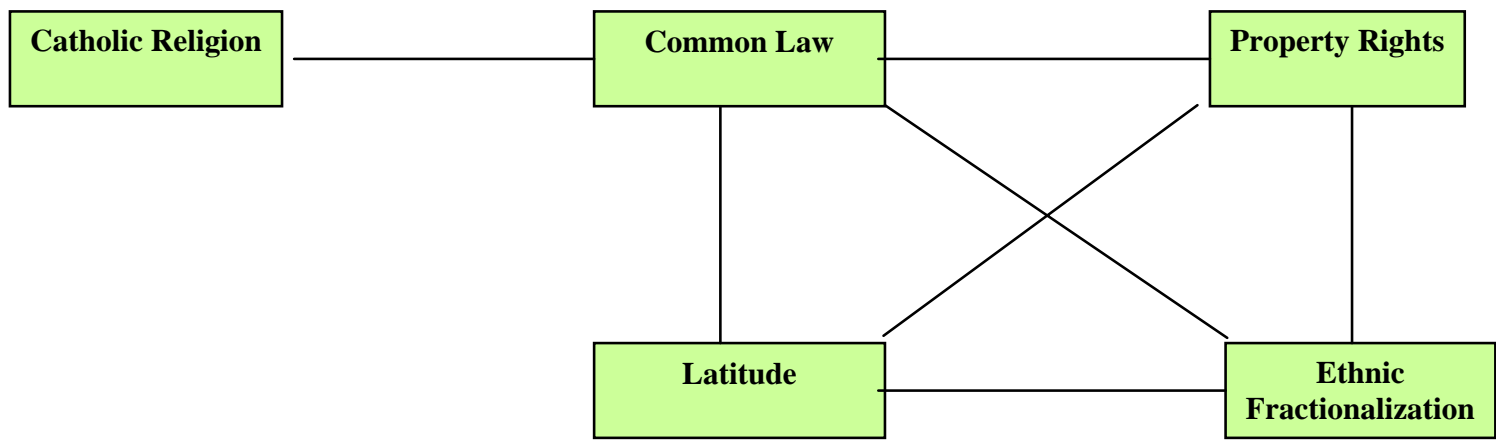

Step 3: Identify the edges with zero conditional correlations: The conditional independence relations found in the data by TETRAD (Table 3) are as follows: 
Note that (iv) is the one and only conditional independence relation found in the data by TETRAD. This implies that all other dependencies assumed in Figure $2 \mathrm{~b}$ remain. The conditioning variable(s) on removed edges between two variables is called the Sepset of the variables whose edge has been removed. Therefore Sepset $($ Common Law, Ethnic Fractionalization $)=$ Latitude After imposition of equation (iv) and removal of the corresponding edges, we are left with the pattern in Figure $\mathbb{C}$ below:

Figure $\mathbb{C}$ :

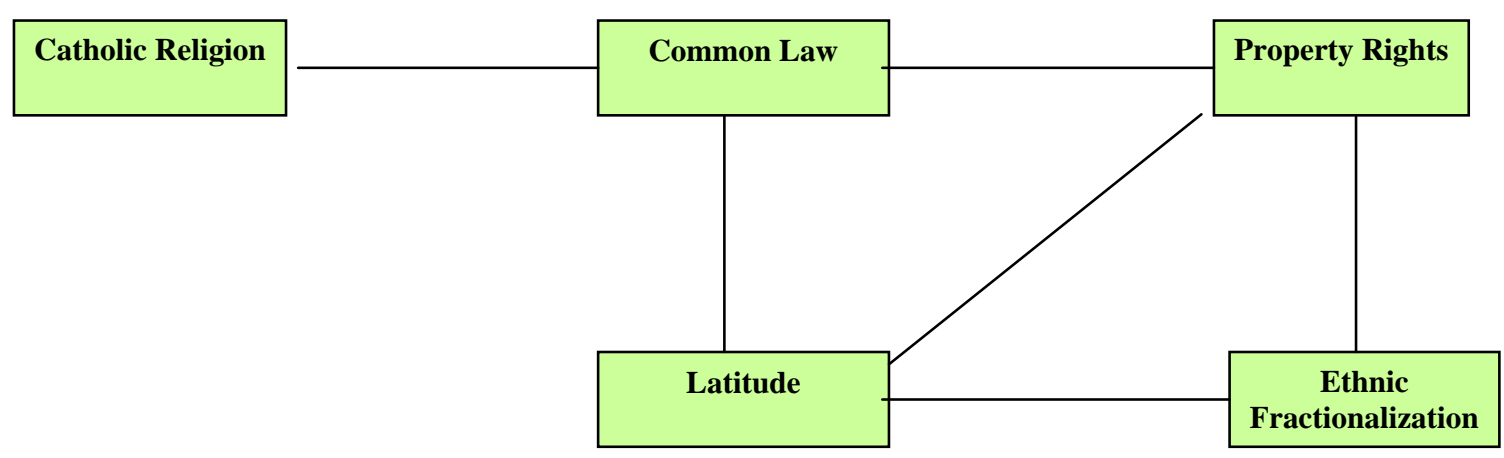

Step 4: Following our discussion of Causal Markov Condition in section 2.1, edges are directed by considering triples $X-Y-Z$, such that $X$ and $Y$ are adjacent, as are $Y$ and $Z$, but $X$ and $Z$ are not adjacent. Edges between triples: $X-Y-Z$ are directed as: $X \rightarrow Y \leftarrow$ $Z$, if $Y$ is not in the sepset of $X$ and $Z$. From Figure 1c we can identify the following sets of triples with directed edges:

Catholic Religion $\rightarrow$ Common Law $\leftarrow$ Property Rights

Catholic Religion $\rightarrow$ Common Law $\leftarrow$ Latitude

Common Law $\rightarrow$ Property Rights $\leftarrow$ Ethnic Fractionalization

Common Law $\rightarrow$ Latitude $\leftarrow$ Property Rights

Common Law $\rightarrow$ Property Rights $\leftarrow$ Latitude

Common Law $\rightarrow$ Latitude $\leftarrow$ Ethnic Fractionalization

Latitude $\rightarrow$ Ethnic Fractionalization $\leftarrow$ Property Rights

Latitude $\rightarrow$ Common Law $\leftarrow$ Property Rights

Latitude $\rightarrow$ Property Rights $\leftarrow$ Ethnic Fractionalization

Ethnic Fractionalization $\rightarrow$ Latitude $\leftarrow$ Property Rights

Note that (x) an inconsistent relation on the basis of the Causal Markov Condition, Common Law $\rightarrow$ Latitude $\leftarrow$ Ethnic Fractionalization since Latitude is in the sepset of Common Law and Ethnic Fractionalization and hence does not figure in the above set.

Assuming a two-tier temporal order where Tier 1 consists of Latitude, Ethnic Fractionalization, Common Law and Catholic Religion and Tier 2 consists of Property Rights, the following relations are forbidden: 
Property Rights $\rightarrow$ Latitude

$(x v)$

Property Rights $\rightarrow$ Common Law

(xvi)

Property Rights $\rightarrow$ Catholic Religion

(xvii)

Property Rights $\rightarrow$ Ethnic Fractionalization

This implies that the only valid directed triples are (vi), (vii), (ix) and (xiii) as shown below in Figure (d):

Combining (xi) to (xix) we have the following pattern in Figure 1d:

Figure (d):

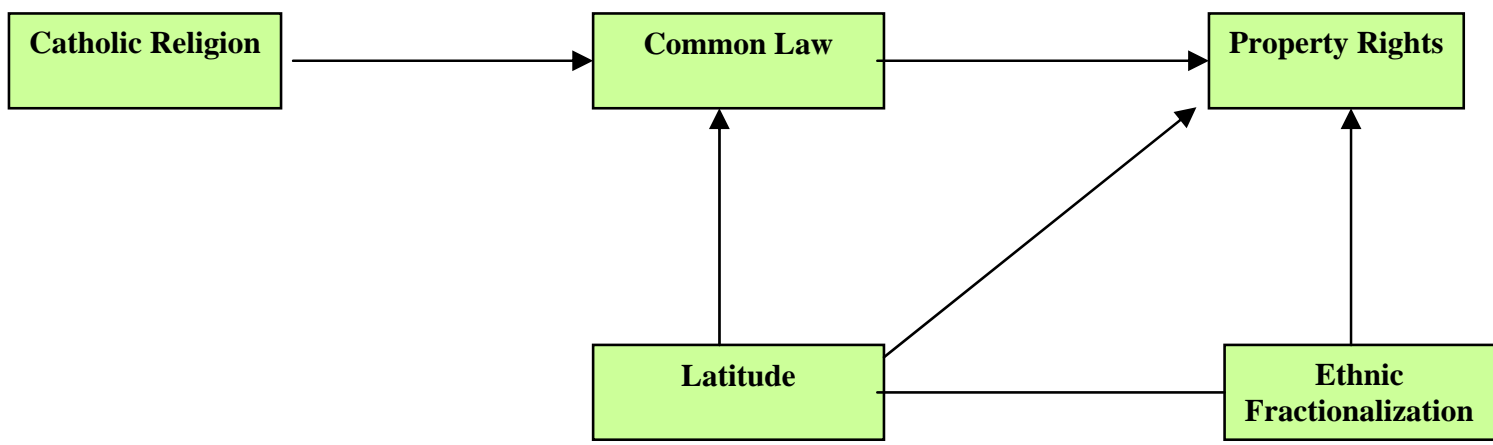

The relationship between Latitude and Ethnic Fractionalization is indeterminate. Figure (d) is consistent with Figure 3b:

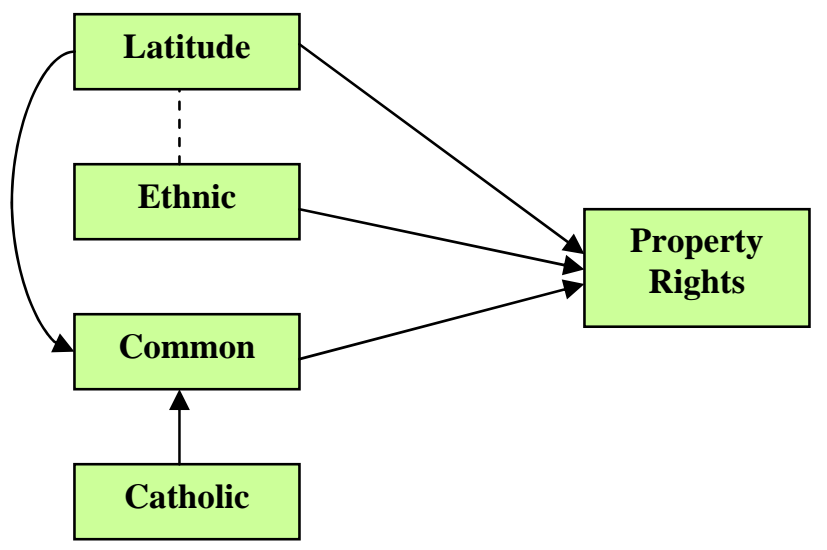

